\title{
5. Fotografie und Propaganda
}

Das Wort Propaganda wird heutzutage zumeist von einer negativen Konnotation begleitet und mit Manipulation und Missbrauch in Verbindung gebracht. In den ersten Jahrzehnten des 20. Jahrhunderts indes wurde darunter vor allem ein Prozess verstanden, in dem Informationen zur Darstellung bestimmter Ziele oder der Sicherung notwendiger Unterstützung kommuniziert wurden. Es handelte sich vornehmlich um die Kontrolle und die Vermittlung von Informationen in erster Linie mit Hilfe und durch Medien ${ }^{1}$ - zumeist Massenmedien, die den jeweiligen politischen, kulturellen oder ökonomischen Interessen entsprachen - an ein interessiertes Publikum. ${ }^{2}$

Roland Barthes zufolge ist die Fotografie hingegen insbesondere eine Information bzw. die Zeitungsfotografie eine Botschaft, die durch die Quelle der Sendung, den Kanal der Übertragung und den Punkt des Empfangs definiert ist. ${ }^{3}$ Die Redaktionsmitglieder sind nach Barthes die Quelle der Sendung, der Kanal der Transmission ist das Medium als solches, während das Publikum den Punkt des Empfangs bildet. ${ }^{4}$ Wenn man eine solche Form der Systematisierung auf die Partisanenfotografie anwendet, sind der Fotograf, die fotografische oder kulturell-künstlerische Sektion, die Zeitungsredaktion, die Druckerei, die Fotound Propagandaabteilung allesamt Quellen der Sendung. Den Transmissionskanal bilden die Zeitungen der Partisanen, in denen man nur selten qualitativ hochwertig abgedruckte, mit Titeln versehene Fotografien finden konnte - weitaus häufiger wurden die entwickelten Bilder selbst oder Wandzeitungen verwendet. ${ }^{5}$ Zeitgenössische Autoren wie etwa Allan Sekula betonen, die Fotografie könne nicht isoliert vom Distributionskontext betrachtet werden. An dieser Stelle sei hervorgehoben, dass im Falle der Partisanenfotografie gar der gesamte Kontext, in dem die fotografische Botschaft der Partisanen funktionieren sollte, heranzuziehen ist. Es handelte sich nicht um gewöhnliche Zeitungsredaktionen, deren Fotografen und Redakteure unter komfortablen Bedingungen arbeiteten, sondern vielmehr

\footnotetext{
1 Kallis, Aristotle. Nazi Propaganda and the Second World War. Hampshire und New York: Palgrave Macmillan 2005, S. 1.

2 Faber, Sebastian. Memory Battles Of The Spanish Civil War. Nashville: Vanderbilt University Press, S. 30.

3 Barthes, Roland. The Photographic Message. In: Sontag, Susan: A Barthes Reader. New York: Hill and Wang 1982, S. 124.

4 Ebd.

5 Die Distributionskanäle der Fotografie offenbarten all ihre negativen Seiten bei der Ankunft der Verbindungsoffiziere des Hauptstabs für den Nahen Osten. Edvard Kardelj schickte am 13. Juni 1943 einen Brief an Boris Kidrič und Franc Leskosek, in dem er ihnen mitteilte, dass ihre Fotografien für politische Zwecke genutzt und in der Zeitung Poročevalec (Berichterstatter) abgedruckt werden sollten. Sich der absoluten Limitiertheit einer solchen Propaganda bewusst, riet er ihnen, dass man sie auch den Bauern in den Dörfern zeigen sollte. In: Zbornik dokumenata i podataka o narodno-oslobodilačkom ratu jugoslovenskih naroda. Bd. II/7: Dokumenta vrhovnog štaba Narodnooslobodilačke vojske Jugoslavije 1942-1943. Belgrad 1959.
} 
um Druckereien, die überwiegend in Wäldern oder in den vorübergehend befreiten Städten und Ortschaften angesiedelt waren. Zudem reduzierten sie sich nicht selten auf die Fotografen selbst.

Mit Blick auf Distributionskanäle ist das Beispiel einer Fotografie interessant, auf der königstreue serbische Tschetniks zusammen mit Offizieren der deutschen Wehrmacht und Anhängern der kroatischen Ustascha in der bosnischen Stadt Sanski Most dem Fotografen Modell standen - und zwar im selben Park, in dem nur ein Jahr zuvor 27 Menschen erhängt worden sind. ${ }^{6}$ Zu erwähnen sind auch Fotografien, auf denen Mitglieder der Ustascha gemeinsam mit Tschetniks am 15. Mai 1942 in Banja Luka posieren. Nachdem die Partisanen über Verbindungsleute und Sympathisanten in den Besitz dieser Fotografien gelangt waren, verteilten sie diese unter der Bevölkerung und sicherten dadurch der Partisanenbewegung eine noch breitere Unterstützung. Die Aktion war vor allem Vilko Vinterhalter, Chef der Agitprop-Abteilung für die Bosanska Krajina und späterer Redakteur der in Sarajevo veröffentlichten Zeitung Oslobodjenje (Befreiung) zu verdanken. ${ }^{7}$ In der Folge stießen die Einheiten der Ustascha auf zunehmend größeren Widerstand der Bevölkerung, worüber ein Tschetnik-Oberst namens Rade Radić, ${ }^{8}$ dem Nachrichtenoffizier der Vierten Infanteriedivision des Unabhängigen Staates Kroatien, Stjepan Kovačević, berichtete: »Das Volk greift uns, und besonders mich, wegen der geschlossenen Abkommen vehement an. ${ }^{9}$

Unter Agitation, die Guerillabewegungen und somit auch die Partisanenbewegung kennzeichnet, war die Verbreitung politischer Ideen mit Hilfe von Worten, Briefen und anderen Mitteln zu verstehen, um eine kritische Masse an Unterstützern für unmittelbare Aktionen oder die Verwirklichung eines bestimmten politischen Zieles zu gewährleisten. Propaganda bedeutete hingegen die planmäßige Verbreitung politischer Grundsätze und die Schulung von Menschen zum Verständnis dieser Prinzipien. Unter Kultur wiederum wurde die Summe »aller materiellen und geistigen Leistungen eines Volkes oder der Menschheit in einem bestimmten Zeitraum « verstanden. ${ }^{10}$ In einem Dokument mit Anleitungen zur Arbeit und Organisation der Agitprop in der Küsten- und Gebirgsdivision ist zu lesen, dass man sich in allen Einheiten - jedem Zug, jeder Kompanie, jedem Bataillon und schließlich auch der Division - »ständig vor Augen führen muss, dass unsere Armee umso stärker ist, je mehr die Kämpfer wissen bzw. je politisch gebildeter, besser informiert, kulturell fortschrittlicher sie sind. Im Gegensatz dazu ist die faschistische Wehrmacht umso stärker, je weniger ihre Soldaten wissen, das heißt je weniger politisch gebildet, informiert und kulturell bewandert sie sind. «" ${ }^{11}$ Die Kommunistische Partei Jugoslawiens vertrat von Beginn an den Standpunkt, dass Kultur und Bildung eine wichtige Form des revolutionären Kampfes darstellen, der sich parallel zum antifaschistischen Kampf vollzieht. Diese Idee illustrierten auch Parolen

\footnotetext{
6 Bokan, Branko J.. Srez Sanski Most u NOB 1941-1945. godine. Sanski Most: Skupština opštine Sanski Most 1980, S. 445

7 Samardžija, Stevo. Četrnaesta srednjebosanska NOU brigada. Banja Luka: Skupština opštine Prnjavor 1983, S. 233.

8 Ebd., S. 233.

9 Arhiv VII, NDH [Unabhäniger Staat Kroatien], Schachtel 101, Reg.-Nr. 2/4-1. Siehe Samardžija, Stevo: Četrnaesta srednjebosanska NOU brigada. Banja Luka: Skupština opštine Prnjavor 1983.

10 Zbornik dokumenata i podataka o narodno-oslobodilačkom ratu jugoslovenskih naroda. Bd. IX/3: Partijsko-politička dokumenta 1943. godine. Belgrad 1967.

11 Ebd.
} 
wie »Durch Bildung zur Freiheit«, »Waffen sind nicht nur Gewehre und Kanonen, Flugzeuge und Panzer, sondern auch Wissen« und »Bücher helfen uns, die Freiheit zu gewinnen, und die Freiheit wird uns ermöglichen, Bücher zu erobern «, ${ }^{12}$ womit das emanzipatorische Potenzial des Partisanenkampfes bestätigt werden sollte.

\section{Intensivierung der Tätigkeiten der Agitprop}

Aufgrund ihrer Eigenschaft, Botschaften relativ leicht zu übermitteln, wurde die Fotografie in der Agitprop-Abteilung zu einem zunehmend wichtigeren Kommunikationskanal und immer bedeutender für die Agitation der Partisanen. Dennoch glitt die Partisanenfotografie zu keinem Zeitpunkt in ausschließliche Propaganda ab. Der Grund für die stetig bedeutendere Rolle der Fotografie lag in der Tatsache begründet, dass in den beiden letzten Kriegsjahren die Zentralisierung der Propaganda- und der kulturell-künstlerischen Abteilungen immer weiter gestärkt wurde, um den bevorstehenden Aufgaben des Volksbefreiungskampfes zu entsprechen. Im Jahr 1943 wurde mit einer Systematisierung des Agitations- und Propagandaapparats sowie der Kultur- und Bildungsräte begonnen. Sie wurden in vier Bereiche eingeteilt: politische Agitation, Zeitungswesen, Kultur- sowie Bildungsarbeit, zu der die Alphabetisierung der Menschen, das Schulwesen, die Organisation von Vorträgen, eine Laientheatersektion, Chöre, Bibliotheken, die Anlegung von Archiven sowie die Fotografie gehörten:

"Jede Agitprop-Abteilung in den Brigaden sollte entsprechend den verfügbaren Möglichkeiten und Mitteln (Fotografen, Fotoapparate und -material) Fotoreporter haben, die Kämpfe, Märsche, Übungen, Lernprozesse, Ruhepausen, Feiern, erbeutetes Material, Gefangene und feindliche Verluste, unsere Gefallenen, die alltäglichen Tätigkeiten, beginnend beim Brigadestab bis hin zum einzelnen Soldaten usw. fotografieren würden. Man muss bedenken, dass Fotografien die wohl objektivsten Bilder und Dokumente unseres Kampfes sind und einen unschätzbaren historischen Wert besitzen. Sie stellen außerdem ein vorzügliches Propagandamaterial dar. Besonders wichtig sind Fotografien, die an vorderster Front aufgenommen werden und die unmittelbaren Kampfhandlungen zeigen. Diese Aufgaben haben allerhöchste Priorität: Wenn in den Brigaden das Material fehlt, hat man sofort der Agitprop-Abteilung der Division Meldung zu machen und dabei zusätzlich die Zahl der Fotoapparate anzuführen, über die die Brigade verfügt. Das gesamte aufgenommene Material gehört dem Stab der Division und ist in Form von nicht entwickelten Filmen zu übergeben. Die Filme wird man danach entwickeln, Kopien für das Archiv der Brigade anfertigen und verdienten Kämpfern ihre Fotografien schenken.«13

Hieraus wird ersichtlich, wie hoch die Beweiskraft der Fotografie veranschlagt wurde. Der Glaube an die Macht und die Wahrheit der Fotografie war insbesondere mit Blick auf ihr Propagandapotenzial enorm. Dem Medium wurde eine größere Aussagekraft als dem ge schriebenen Wort zugewiesen. An diesem Punkt setzte die Indexierung der wichtigsten

\footnotetext{
12 Petranović, Branko. Istorija Jugoslavije 1918-1988. Bd. 3: Socijalistička Jugoslavija 1945.-1988. Belgrad: Nolit 1988. S. 357.

13 Zbornik dokumenata i podataka o narodno-oslobodilačkom ratu jugoslovenskih naroda. Bd. IX/3: Partijsko-politička doku-

menta 1943. godine. Belgrad 1967.
} 
Themen ein, aber es deutete sich auch die künftige Anlegung von Fotoarchiven an. Hinsichtlich der Wahl der Themen überwog ein horizontaler Ansatz, doch wichtig waren auch Mußestunden sowie jeder einzelne Soldat, ungeachtet seiner Position innerhalb der militärischen Hierarchie.

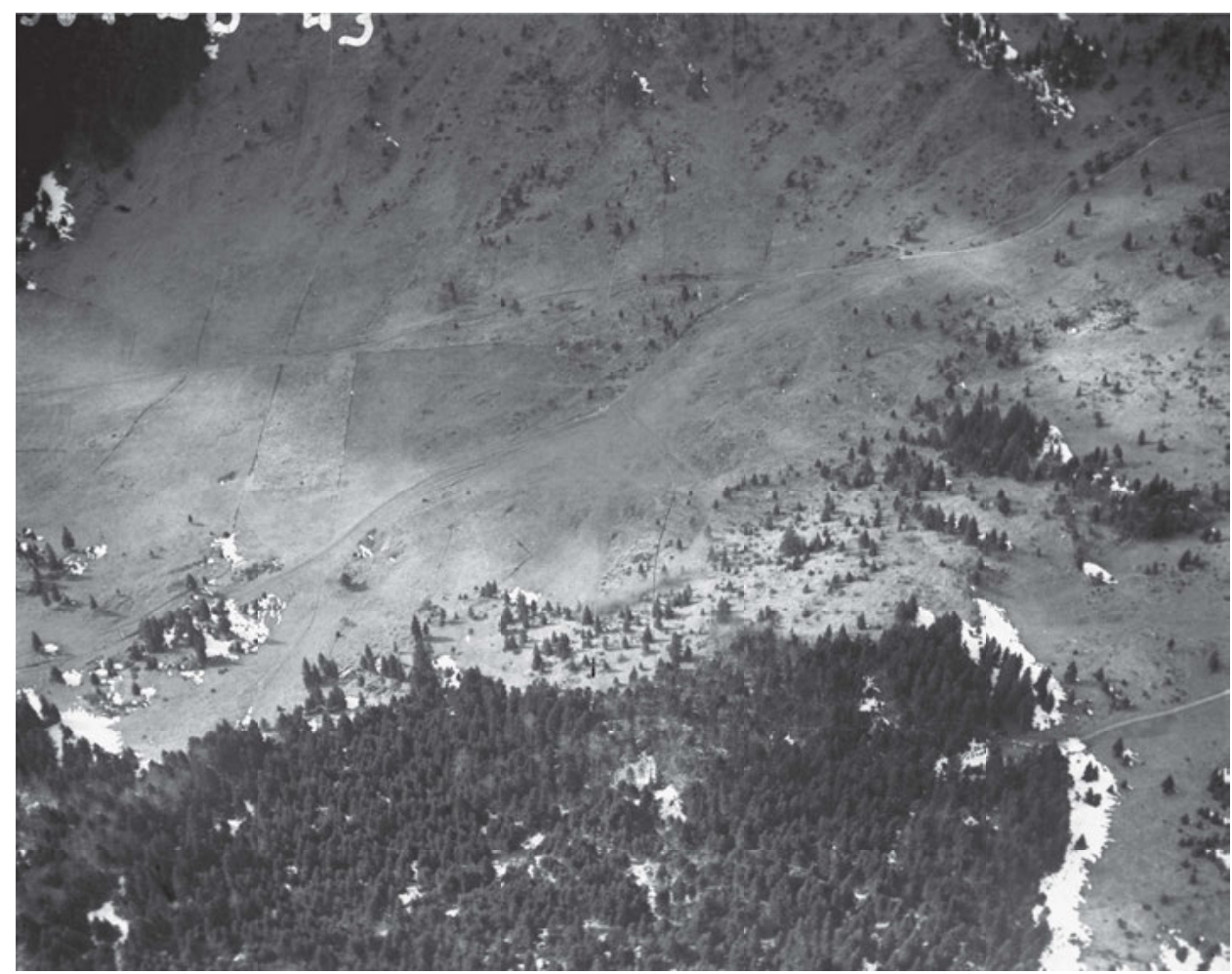

Höchstwahrscheinlich eine Aufnahme aus einem Flugzeug der Allierten, 1944/45. Ljubljana, Museum für Neuere Geschichte Sloweniens | TN1119/8.

Die größte Zahl der Fotosektionen wurde nach dem Befehl des Oberkommandos vom 13. Dezember 1944 zur Organisation der Propaganda- sowie der Kultur- und Bildungsarbeit innerhalb der Volksbefreiungsarmee systematisch eingerichtet. Die Fotosektionen sollten in der Propagandaabteilung des Hauptstabs sowie in den Stäben der Divisionen und Brigaden gemeinsam mit Filmsektionen ihrer Arbeit nachgehen. Die Propagandaaktivitäten erlebten Ende 1944 ihren größten Aufschwung, sie durchdrangen die gesamte Struktur, angefangen bei den kleinsten militärischen Formationen, über Bataillone und Kompanien bis hin zum Hauptstab selbst, der Abteilungen für Propaganda, Kultur- und Bildungsarbeit, Zeitungswesen, Film, Fotografie und historisch-wissenschaftliche Arbeit erhielt. ${ }^{14}$ Die Kritik an dieser Art der Organisation richtete sich zumeist gegen die "schablonenhafte Herangehensweise an die Formen der Arbeit und die Realisierung der Kultur- und Bildungsaktivitäten ${ }^{15}$ Gleichzeitig übernahmen die Kulturabteilungen in den Brigaden maßgeblich die 


\section{4. Čega treba da se drže vojni cenzori a svome radu?}

Cilj rada vojnih cenzora treba da bude:

a) da spreče rasturanje knjiga, publikacija,filmova $i$ odašiljanje pošte koji su po svome sadł̌aju upereni protiv tekovina naše borbe, usmereni na razaranje pozadine, demobilisanje snaga za ratne napore, izazivanje šovinistickih i sl.trvenja 1 sukoba, slabłjenje borbenog morala $i$ ratnih napora $i$ na to da neprijatelju otkriju-svesno ili nesvesno - naše vojne tajne(položaj jedinica, obezbed jenje,brojno stanje,namere $i$ zadatke, o jacini i vrstama naoruźanja, vojne objekte za prebacivanje i smeštáj trupa,preduzeća za proizvodnju ratnog materijala 11 vojne opreme, mesta $i$ kapacitet naših tvornica,brojno stanje radnika, podatke o predvidjenom putovanju, pravcu i nacinu putovanja vojnih $i$ politčkih rukovodilaca,o mestima naših magacina, skladišta,načinu prevoza ratnog 1 vojnog materijala itd.).

b) da speče rasturanje svih knjiga,filmova,foto-materijala, publikacija, žurnala i sl.Koji su proizvod fašisticke odnosno kvislinske propagande, u kojima se pronose fašisticke tendencije, brane ili slave narodni izdajnici i sluge okupatora pa bilo da su one štampane, slikane ili snimane za vreme okupacije,pre okupacije ili posle oslobodjenja.

c) da spreče izdavanje i rasturanje,odnosno samo rasturanje stvari snimanih ili štampanih za vreme okupacije,koje bi štetile ratnim naporima savezničkih država ili išle na stetu - moralno ili materijalno $I$ armija savezničkih država.Tako je odredjen opseg rada $i$ kriterijuma $o j n i h$ cenzora u $c 1.4$ Uredbe $i$ njega se treba $\$$ potpuno pridržavati.Treba se Cuvati toga da vojni cenzori ne postunu kočnica književnog $i$ umetnickog razvoja.za eenzore treba da bude bitno ne da 11 je neka stvar nla dovoljnoj umetničkoj visini, nego da li je ona neprijateljska ili fašisticka. Pogrešno bi bilo da vojni cenzori

Anweisung des Generalstabs, Fotosektionen in den Korps und Brigaden zu gründen, 3. Oktober 1944. Belgrad, Militärarchiv | NOVJ K393 F2 19.

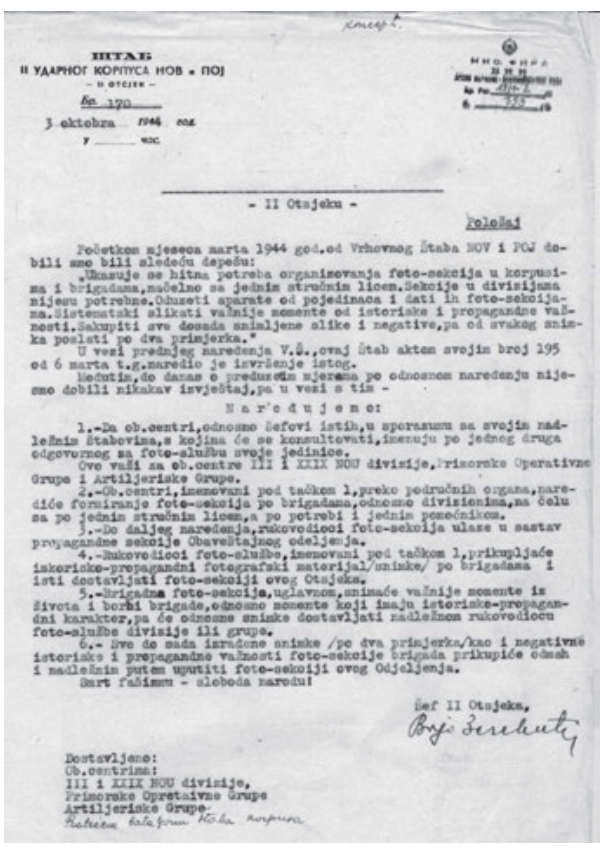

Anweisung des Generalstabs, Fotosektionen in den Korps und Brigaden zu gründen, 6. März 1944. Belgrad, Militärarchiv | NOVJ K392 F2 28.

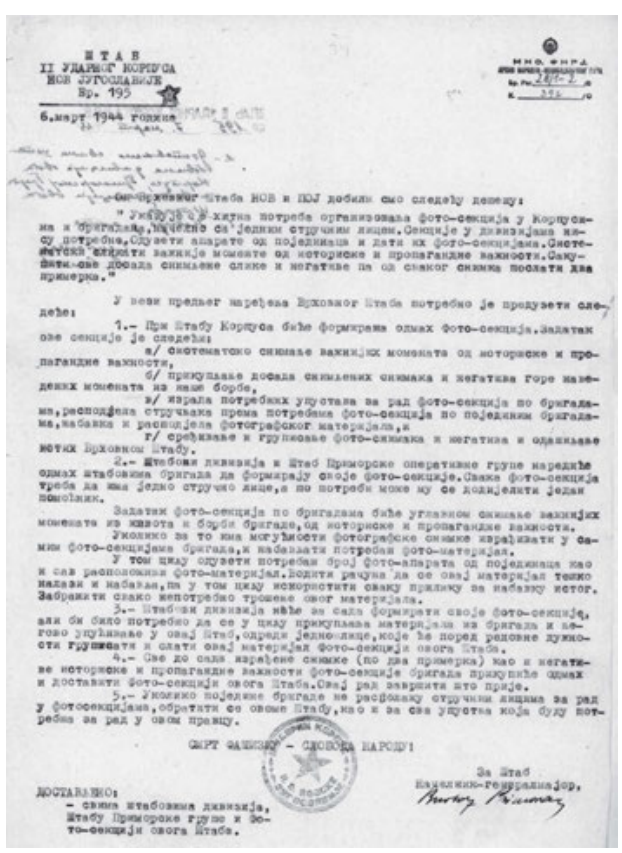

Schreiben mit dem Titel „Was müssen Militärzensoren bei ihrer Arbeit beachten?". Belgrad, Militärarchiv | NOVJ K440C F2 20. 
Agitations- und Propagandaarbeit, die Kultur- und Bildungstätigkeit. Im selben Jahr wurden Fotodienste gegründet, die Aufnahmen aus der Luft unter anderem für die Verwendung in der Landvermessungssektion fertigen sollten. ${ }^{16}$ Als einziger Widerstandsbewegung war es den Partisanen gelungen, Fliegerstaffeln zu organisieren. Durch die Entwicklung der Luftwaffe kam es auch zur Gründung eines separaten Dienstes für Luftaufnahmen, der Aufklärung aus der Luft betreiben und nachrichtendienstliche Aufgaben übernehmen sollte. Für die Vorbereitung der abschließenden Kriegsoperationen und die Befreiung des Landes waren diese Tätigkeiten von entscheidender Bedeutung. Die aus der Luft getätigten Aufnahmen wurden vergrößert und zu größeren Einheiten verbunden.

Die Anweisungen für die Arbeit des Pressedienstes vom März 1944 erläutern die besondere Bedeutung der Fotografien und enthalten die Aufforderung an die Berichterstatter, alle Fotografien aus dem Volksbefreiungskampf sowie Aufnahmen feindlicher Verbrechen zusammenzutragen. Eine recht optimistische Empfehlung lautete überdies, dass man Fotografien sammeln sollte, die sich »in den Taschen der Leute befinden, die diese für die Verwendung der Widerstandsbewegung gerne hergeben werden. $«^{17}$ Das Oberkommando erteilte daher am 4. März 1944 dem Hauptstab der Volksbefreiungsarmee und der Widerstandsbewegung Kroatiens den dringlichen Befehl, in den Brigaden und Korps Fotosektionen einzurichten, deren Aufgabe im Fotografieren relevanter Ereignisse bestand. Angeraten wurde, Fotoapparate, die einzelne Partisanenkämpfer besaßen oder ihnen überlassen wurden, einzusammeln und sie den Fotosektionen zurückzugeben: "Systematisch sind alle Ereignisse von historischer und propagandistischer Bedeutung zu fotografieren sowie alle bislang gefertigten Abzüge und Negative zu sammeln und von jeder Aufnahme zwei Abzüge einzuschicken. ${ }^{18}{ }^{18}$ Denselben Befehl erhielten in den darauffolgenden Tagen auch alle anderen Stäbe, denen man zudem auferlegte, Anleitungen für die Arbeit der Fotosektionen zu erstellen.

Die Versuche einer stärkeren Zentralisierung des Agitprop-Apparats im Verlauf des Jahres 1944 bewirkten allmähliche Veränderungen, was im Beschluss der KPJ mündete, dass ein neuer Propagandadienst ins Leben gerufen werden sollte:

„Die neue Organisation der Agitprop-Abteilung des Zentralkomitees war auf die Überwindung der 'Spontanität und Archaikı, den Aufbau des Agitprop-Apparats, die Konzentrierung - mittelbar oder unmittelbar - des gesamten volkseigenen, politischen, kulturellen, schulischen, ja auch des wissenschaftlichen Lebens in den Händen der parteilichen Einrichtungen ausgerichtet. «19

Auf diese Weise sollte die Zahl der Parteimitglieder gesteigert und die ideologische Grundlage einer neuen Gesellschaft geschaffen werden. Das letzte Kriegsjahr und das Kriegsende stellten für die Fotografie einen Wendepunkt dar, da sie nunmehr unter die absolute

16 Zbornik dokumenata i podataka o narodno-oslobodilačkom ratu jugoslovenskih naroda. Bd. V/26: Borbe u Hrvatskoj 1944. godine. Belgrad 1961.

17 Zemaljsko antifašističko vijeće narodnog oslobođenja Hrvatske, zbornik dokumenata 1944. (od 10. svibnja do 31. prosinca). Zagreb: Institut za historiju radničkog pokreta Hrvatske 1975.

18 Zbornik dokumenata /podataka o narodno-oslobodilačkom ratu jugoslovenskih naroda. Bd. II/12: Belgrad 1971.

19 Petranović, Branko. Istorija Jugoslavije 1918-1988. Bd. III: Socijalistička Jugoslavija 1945. -1988. Belgrad: Nolit 1988, S. 121. 
Kontrolle eines Massenapparats fiel. Zugleich setzte langsam eine Periode ein, die der Historiker Branko Petranović beschrieb als Zeit ohne »Kritik, Disput, Pluralität der Standpunkte über spezifische Themen aus dem Bereich des kulturellen Schaffens - wenn man von einzelnen kritisch intonierten Artikeln mit politischem Hintergrund aus den Reihen der sogenannten bürgerlichen Opposition absieht« ${ }^{20}$ In dieser Phase ging das Partisanenarchiv in die Hände zentralisierter Ämter über. Sie wurden zu Einrichtungen des neu entstandenen Staates, der eine souveräne Kontrolle auch durch den Aufbau einer dogmatischen ideologischen Position in der gesamten Gesellschaft zu sichern bemüht war. Einer der Gründe für diese Wende lag auch im Umstand begründet, dass die Entstehung eines neuen Staates nicht ohne Widerstände und Probleme im In- und Ausland verlaufen konnte; vor allem vonseiten der Sowjetunion waren direkte Drohungen einer Invasion zu vernehmen.

Die Propagandaabteilungen in den Brigaden- und Divisionsstäben hatten im Jahr 1945 Sektionen für Politik und Propaganda, Kultur und Bildungswesen, für Fotografie sowie Presse. Die Propagandaabteilungen in den Korps besaßen darüber hinaus Abteilungen für politische Propaganda sowie Kultur- und Bildungsabteilungen mit Sektionen für Schulbildung, Alphabetisierungskurse und Kunst, ferner Abteilungen für Zeitungswesen, Film und Fotografie. Das Oberkommando der Volksbefreiungsarmee und der Widerstandsbewegung Jugoslawiens sowie ab dem 1. März der Generalstab der Jugoslawischen Armee (JA) verfügten über eine Abteilung für politische Propaganda und eine Abteilung für Kultur und Bildung mit drei Sektionen: Allgemeinbildung, Alphabetisierungskurse und Kunst, darüber hinaus Abteilungen für Zeitungswesen, ein Institut für die Erforschung des Volksbefreiungskrieges, eine Fotosektion sowie eine Abteilung für Auslandsbeziehungen und Personalangelegenheiten.

Entgegen der heute gängigen Meinung wurde in Jugoslawien die Militärzensur erst Anfang 1945 eingeführt und war auf die Kontrolle der Inhalte innerhalb des Militärs gerichtet. Gemäß dem Dokument des Oberkommandos waren die Hauptstäbe für die Einführung der Zensur verantwortlich. Vollzogen wurde die Zensur von den Beauftragten in den Stäben der Korps und der unter ihre Zuständigkeit fallenden militärischen Gebiete sowie bei Bedarf auch in den Stäben der Brigaden und Kompanien. Militärische Zensoren waren Organe der Stäbe, während die militärische Postzensur von mit diesem Amt betrauten Kommandos ausgeübt wurde. Zum ersten Mal wurde ein Verzeichnis mit Titeln verbotener Bücher erstellt und zudem sämtliche aus dem Ausland stammenden Manuskripte und Bücher samt detaillierter Beschreibungen kontrolliert. Für Filme legte man ein besonderes Verzeichnis an, das neben den Filmdaten auch die Verbotsgründe nannte. Wegen Materialmangels verzichtete man interessanterweise auf die Vernichtung der konfiszierten Filme, um sie später bei Bedarf wiederverwerten zu können. Offizielle Schreiben wie die Briefe des Oberkommandos, aber auch Briefe von Zivilisten, die an andere Zivilisten oder Soldaten gerichtet waren, unterlagen nicht der Zensur. Kontrolliert wurden hingegen die Berichte von Journalisten, alle Nachrichten der Berichterstatter sowie Fotomaterial, das für unterschiedliche offizielle Zeitungsausgaben bestimmt war. Verhindern sollte die Zensur die Verbreitung feindlicher Inhalte und Propaganda von Kollaborateuren, die Preisgabe von militärischen 
Geheimnissen sowie die Distribution von Materialien, die während der Okkupation gedruckt wurden und die in irgendeiner Form die Anstrengungen der Alliiertenverbände hätten gefährden können. Dabei hob man besonders hervor, dass die Militärzensur nicht die literarische und künstlerische Entwicklung bremsen dürfe und es nicht ihre Aufgabe wäre, den Wert des künstlerischen Werks zu beurteilen, sondern lediglich zu entscheiden, ob ein Werk feindlichen oder faschistischen Charakters war. ${ }^{21}$ Anders als bei den Alliierten und den feindlichen Streitkräften wurde der Zensurapparat erst im letzten Kriegsjahr Realität. Diese Tatsache ist vor allem in Hinblick auf die fotografische Tätigkeit interessant. Gerade das Fehlen von Kontrolle trug ja zum Pluralismus von Ideen und Ansätzen bei, der zusammen mit den Produktionsbedingungen die Partisanenfotografie maßgeblich prägte. Im übertragenen Sinne standen der demokratische Aspekt des Mediums und die fotografische Produktionspraxis in Distanz zu autoritären und bürokratischen Praktiken, die in anderen Feldern geherrscht hatten. Die Partisanenfotografen waren innerhalb der antifaschistischen Bewegung vielleicht dem Ideal des horizontalen antikapitalistischen Kampfes am nächsten, das heute unter verschiedenen gesellschaftlichen Bewegungen in der Welt allgegenwärtig ist.

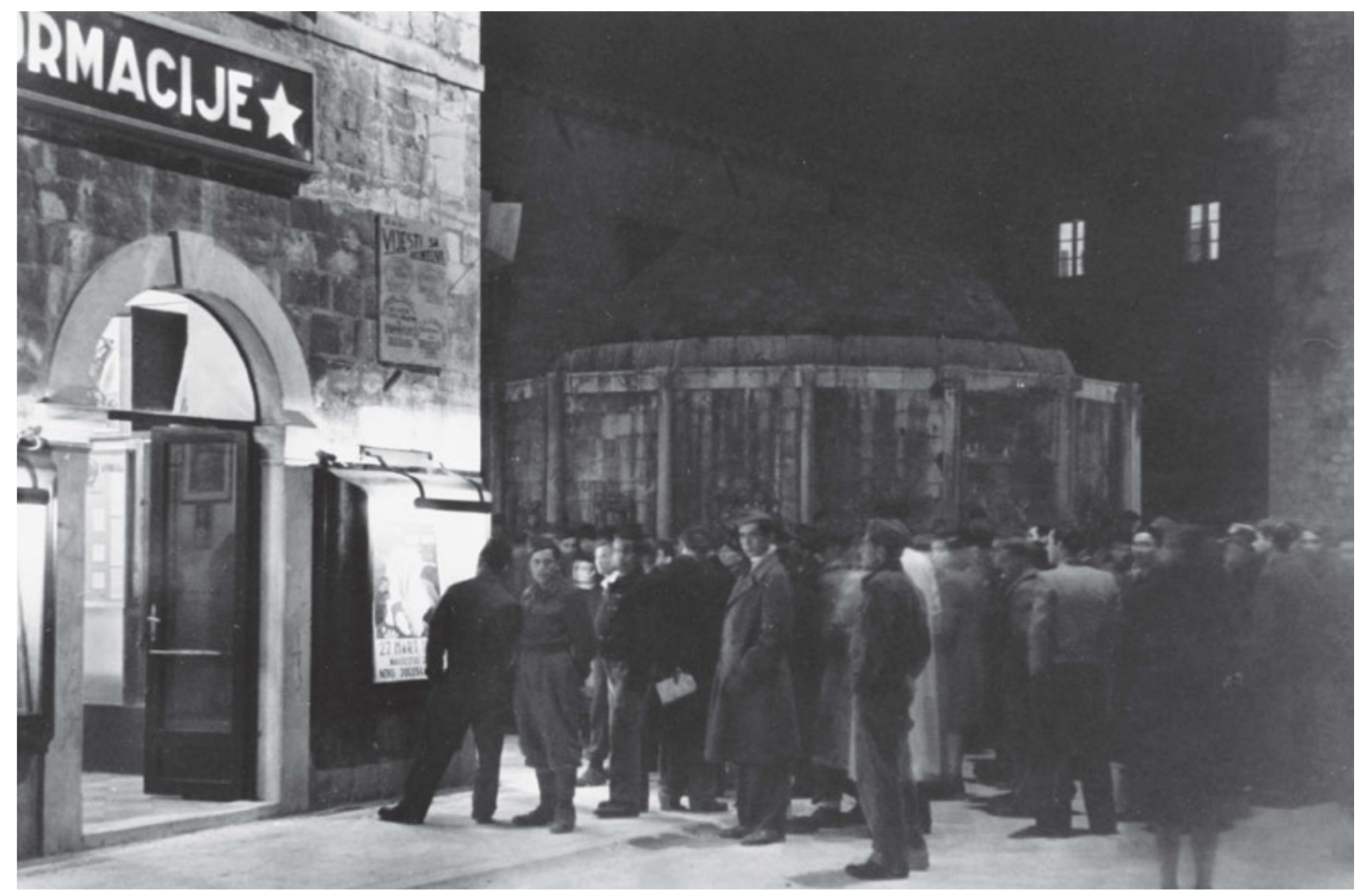

Warten auf Radionachrichten vor dem Informationsbüro in Dubrovnik, 1945. Foto: Nikola Ruočić. Zagreb, Kroatisches Historisches Museum | HPM/MRNH-F-8242. 


\section{Feindliche Propaganda}

Während der gesamten Kriegszeit folgte das Kultur- und Schulleben innerhalb der okkupierten Territorien der Ideologie des Faschismus und Nationalsozialismus. Die Inhalte waren ausgesprochen antikommunistisch, antijüdisch und antifreimaurerisch, auf dem Gebiet des Unabhängigen Staates Kroatien auch antiserbisch und antijugoslawisch. Die deutsche Kultur wurde ebenso wie das antike Rom glorifiziert. Als Fremdsprachen im Schulunterricht unterrichtete man nun die Sprachen der Achsenmächte: Deutsch, Italienisch, Bulgarisch und Ungarisch. ${ }^{22}$ Die italienische Besatzungsmacht gründete in Split eine Abteilung für faschistische Kultur.

Eine der größten, vorrangig gegen Freimaurer, Kommunisten und Juden gerichteten Propagandaausstellungen im besetzten Serbien war die sogenannte Antimasonische Ausstellung, organisiert durch profaschistische Journalisten wie Milan Stojadinović, der während der Besatzung an der Spitze der Propagandaabteilung des Regierungspräsidiums stand, sowie Djordje Perić, Chef der staatlichen Propaganda. ${ }^{23}$ Die Partisanen wurden auf den Plakaten und in den Berichten der Deutschen, insbesondere jedoch seitens der einheimischen Vasallenstaaten als Brandstifter und sexuell ausschweifend lebende Menschen dargestellt, die nicht einmal vor der Ermordung ihrer eigenen Geschwister zurückschreckten.

Im Unabhängigen Staat Kroatien war für die Fotografie das Lichtbildbüro der Staatlichen Nachrichten- und Propagandabehörde des Regierungpräsidiums des Unabhängigen Staates Kroatien zuständig, das der Schriftsteller und Fotograf Ivan Soft (mit Unterstützung des Leiters der Filmabteilung Mladen Grčević) von 1941 bis 1943 leitete. ${ }^{24}$ Die Aufgabe des Büros bestand darin, jegliches Propagandamaterial zu sammeln; die Fotosammlung zählte bereits im Jahr 1942 insgesamt 3.000 Fotografien und Negative. ${ }^{25}$ Im Februar 1943 bildete sich eine neue Propagandastruktur innerhalb der Oberdirektion für Propaganda heraus. Es erfolgte die Gründung einer Abteilung für Presse und Fotografie, die wiederum in die Teilbereiche Zeitungswesen, Fotografie und Film untergliedert war. ${ }^{26}$ Gleichzeitig gab man auch Fotomonografien wie jene mit dem Titel Lijepa naša domovino (Unsere schöne Heimat) heraus.

Wie die Propaganda im Unabhängigen Staat Kroatien funktionierte, lässt sich am Beispiel des Fotografen Edmund Stoger zeigen, der Anfang September 1942 im Konzentrationslager Jasenovac eintraf. ${ }^{27}$ Während seines achttägigen Aufenthalts in Jasenovac machte Edmund Stoger nicht nur Fotos, sondern drehte auch einen Propagandafilm mit dem Titel Pozitivni rad u logoru Jasenovac (Positive Arbeit im Lager Jasenovac), der im Rahmen der Zagreber

22 Petranović, Branko. Istorija Jugoslavije 1918-1988. III: Socijalistička Jugoslavija 1945.-1988. Belgrad: Nolit 1988, S. 358359.

23 Radanović, Milan. Anitmasonska izložba. In: Pisarri, Milovan und Rädle Rena (Hrsg.). Mesta stradanja i antifašističke borbe u Beogradu 1941-44. Priručnik za čitanje grada. Belgrad: Rosa Luxemburg Stiftung Southeast Europe 2016, S. 74.

24 Hlevnjak, Branka und Ivanuš, Rhea. Hrvatska antiratna fotografija: Prvi svjetski, Drugi svjetski i Domovinski rat. Zagreb: Udruga za promicanje oblikovanja i umjetnosti, Design Art d. o. o., Centar za kulturu i obrazovanje 2008, S. 101.

25 Mataušić, Nataša. Koncentracioni logor Jasenovac. Zagreb: Spomen-područje Jasenovac 2008, S. 46.

26 Labus, Alan. Upravljanje medijima, cenzura, te položaj i uloga novinara u Nezavisnoj Državi Hrvatskoj. In: Studia lexicographi-

ca, Jg. 3, Nr. 1-2 (3-4), S. 107-108.

27 Mataušić, Nataša. Koncentracioni logor Jasenovac. Zagreb: Spomen-područje Jasenovac 2008, S. 28-29. 
Herbstmesse 1942 vorgeführt wurde. Unter der Parole »hre frühere Arbeit war Politik - unsere heutige Politik ist Arbeit« wurden in einer Baracke die Bedingungen im Lager sowie sein Arbeits- und angeblich auch Besserungscharakter nachgestellt. In der Ausstellung befanden sich unter anderem Zeichnungen des jungen Daniel Ozma, der am 5. September 1942 durch Erschießung hingerichtet wurde, nur einige Tage nachdem seine Mutter, sein Bruder und seine Schwester in Jasenovac umkamen. ${ }^{28}$ Stoger fertigte in Jasenovac Aufnahmen zu Propagandazwecken an, auf denen die unmenschlichen Bedingungen im Lager und die primitiven »Manufakturen«, in denen »manuelle Arbeit der höchsten Brutalität» verrichtet wurde, nicht zu sehen waren. ${ }^{29}$ In dem Bericht einen anonymen Reportes ist festgehalten:

"Die Ausstellung ist in einer Baracke untergebracht, die sonst als Unterkunft für die Lagerinsassen dient. Die Baracke ist außen von Stacheldraht umgeben, während an jedem Ende ein Wachhäuschen steht, von dem aus die Ustascha die Insassen bewachen. Man war nämlich bestrebt, ein möglichst getreues Bild zu erhalten und auf die gleiche Weise wie in den Konzentrationslagern zu arrangieren. Am Eingang in die Baracke, in der die Ausstellung organisiert wurde, fand sich das Wappen der Ustascha und unter inm folgende Inschrift: >Alles für den Staatsführer - Ustascha-Verteidigung< [...]. Jahrelang lebten Juden, Freimaurer und innen vergleichbare Menschen auf Rechnung des kroatischen Volkes. Sie drangen in alle Sphären des Lebens vor, getrieben vom Wunsch, das kroatische Volk in größtmöglichem Maße für sich auszunutzen. Dies war ein Albtraum, der all unsere Volksschichten zu erdrücken drohte, ein Albtraum, gegen den ein Kampf unmöglich war, weil diejenigen, die damals Kroatien regierten, innen stets zur Hand gingen und mit ihnen jedes Mal zusammenarbeiteten, wenn dem kroatischen Volk Schaden zugefügt werden sollte [...]. Die Ausstellung Godinu dana sabirnih logora Ustaške obrane [Ein Jahr der Konzentrationslager der Ustascha-Verteidigung] erregte bei den Besuchern der ZM [Zagreber Messe Anmerkung D. K.] die größte Aufmerksamkeit. Der hölzerne Bau, in dem die Ausstellung stattfand, war stets gut besucht und die Besucher schauten sich einzelne Teile der Ausstellung mit besonderem Interesse an. Angefertigt wurden alle Gegenstände, die notwendig waren, wobei als Beispiel genannt sei, dass man auch mit dem Bau eines Ofens für die Bedürfnisse des Lagers begann, weil passende Öfen ansonsten nicht zu beschaffen waren. « ${ }^{30}$

Zur gleichen Zeit war Vice Lisičić als einem von wenigen Fotografen gestattet, das Büro von Ante Pavelić zu fotografieren. ${ }^{31}$ Obwohl auch andere Fotografen Pavelić porträtierten, sagte Lisičić über seine eigene Erfahrung Folgendes:

»Es war eine richtige Qual, Pavelić fotografisch zu porträtieren, weil er auf allen Fotografien genauso aussah, wie er auch in Wirklichkeit war: düster und mit dem bekannten verbrecherischen Gesichtsausdruck. Seiner Ehegattin, `der Pharaonin Mara‘, gefielen diese Fotografien natürlich

28 Israeli, Raphael. The Death Camps of Croatia. Visions and Revisions, 1941-1945. New Brunswick \& London: Transaction Publishers 2013, S. 166

29 Mataušić, Nataša. Koncentracioni logor Jasenovac. Zagreb: Spomen-područje Jasenovac 2008, S. 171-172.

30 Hrvatski narod, Njihov prijašnji rad bila je politika - sadašnja naša politika jest rad, 09.11.1942, Nr. 524. Siehe Mihaljević, Nikica. Krvavi ustaški Disneyland: Srbi su lijeni, Židovi drski. In: Express, 02.07.2016. Siehe https://www.express.hr/life/krvavi-ustaski-disneyland-srbi-su-lijeni-zidovi-drski-5978\# [Aufruf am 02.02.2021].

31 Hlevnjak, Branka und Ivanuš, Rhea. Hrvatska antiratna fotografija: Prvi svjetski, Drugi svjetski i Domovinski rat. Zagreb: Udruga za promicanje oblikovanja i umjetnosti, Design Art d. o. o., Centar za kulturu i obrazovanje 2008, S. 105. 
nicht, sodass auf ihre ausdrückliche Weisung hin die Aufnahmen unendlich oft wiederholt wurden. Und zwar immer so lange, bis es `der gnädigen Führergattin` zu bunt wurde. Schließlich fand sie eine Lösung, wie ihr Mann vor den Fotografen etwas weicher wirken könnte: Sie verlangte, ihm beim Posieren Witze zu erzählen. Ein natürliches Lächeln auf seinem Gesicht bemerkte ich nur dann, wenn er seinen geliebten Sohn Velimir auf dem Pferd reitend oder beim Spiel auf der Geige sah. $\mathbb{1}^{32}$

Die Ustascha-Propaganda schrieb den Partisanen moralische Degeneration zu und sah sie unter jüdischer Führung. Julije Makanec, einer ihrer Chefideologen, sprach den Partisaninnen ab, die Rolle der Mutter und Frau zu erfüllen: Sie seien ehemalige Prostituierte und »instabile Frauen, die sich ihren weiblichen Instinkten und der Mutterrolle widersetzen ${ }^{33}$

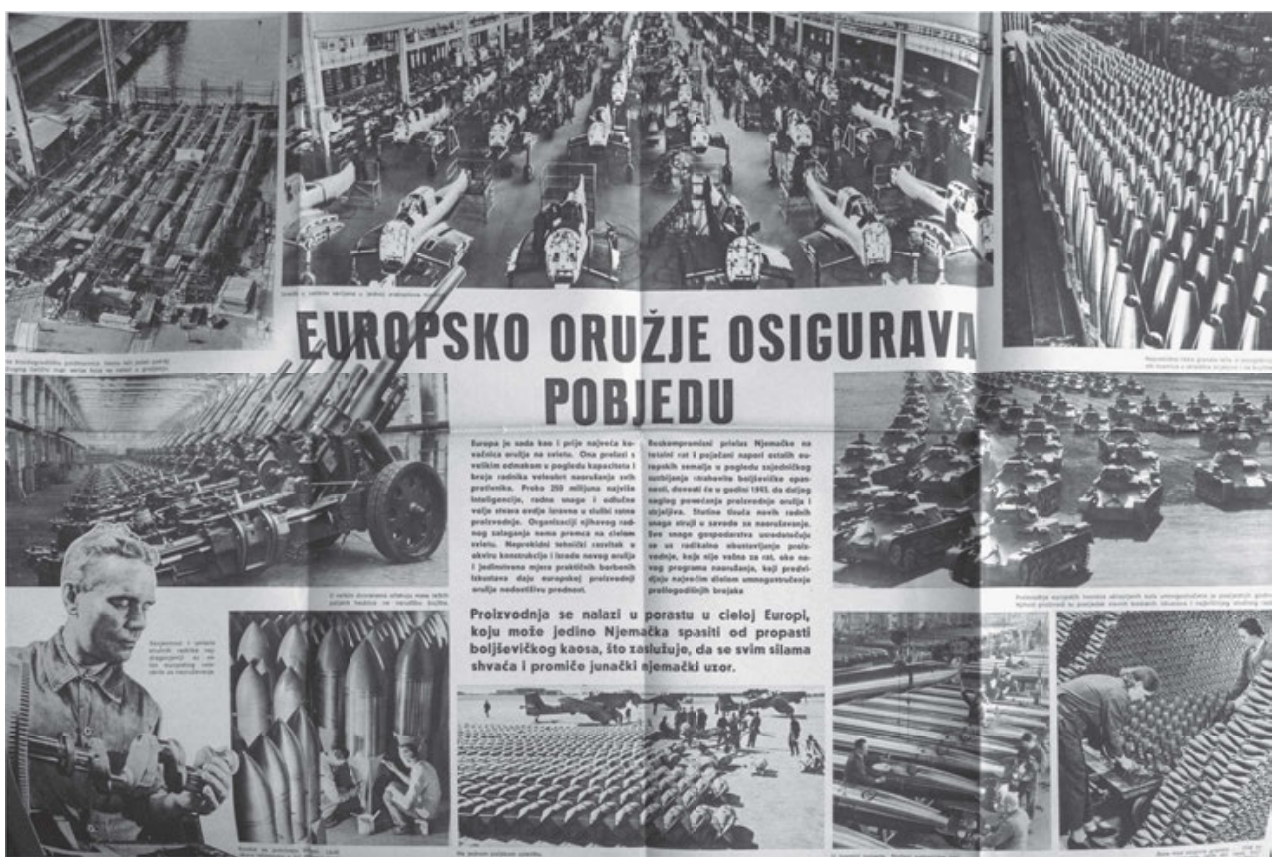

Plakat »Europäische Waffen sichern den Sieg«. Sarajevo, Archiv von Bosnien und Herzegowina | FOND NDH

In Zagreb blieben die Fotografen auch während des Krieges aktiv, sodass der Fotoklub Zagreb 1941 über 400 Fotografien in einer Ausstellung mit dem Titel Lijepa naša domovino (Unsere schöne Heimat) im Künstlerpavillon vorstellte. Gleichzeitig erschienen in Slowenien zahlreiche Zeitschriften der Italiener, der Deutschen und der Landwehr. Die erste Ausgabe der Zeitschrift Slvensko domobranstvo (Slowenische Landwehrbewegung) stellt ein ungewöhnliches Beispiel für die Verwendung beschlagnahmter Fotografien dar. Im Artikel Komunistička buržoazija in nijhov proleterijat (Kommunistische Bourgeoisie und ihr Proletariat) versuchte man den Dichter Matej Bor durch eine bohemistisch-bourgeoise Darstellung mit einer Flasche Wein in der Hand und umgeben von jungen Mädchen zu diskreditieren.

32 Vojinović, Aleksandar. Ante Pavelić. Zagreb: Centar za informacije i publicitet 1988, S. 16.

33 Yeomans, Rory. Visions of Annihilation: The Ustasha Regime and the Cultural Politics of Fascism, 1941-1945. Pittsburgh:

University of Pittsburgh Press 2013, S. 315-316. 


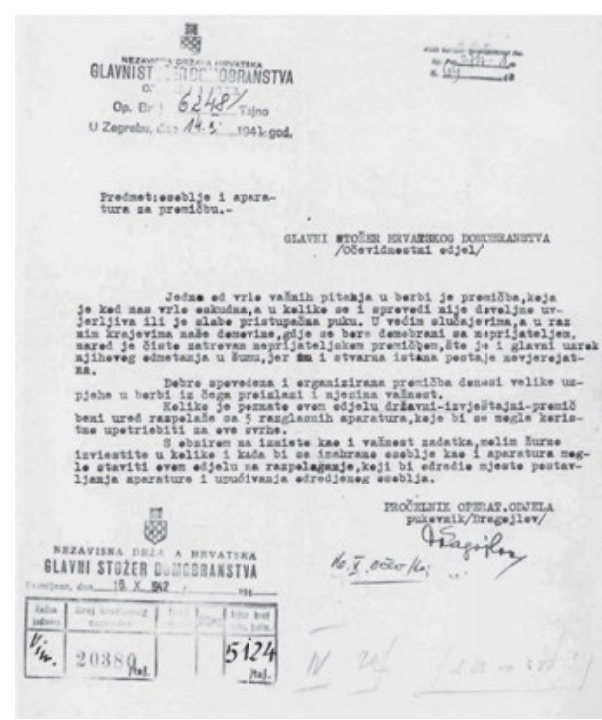

Propagandaaufruf des Hauptstabes des Unabhängigen Staates Kroatien. Belgrad, Militärarchiv | NDH K69 F7 27.

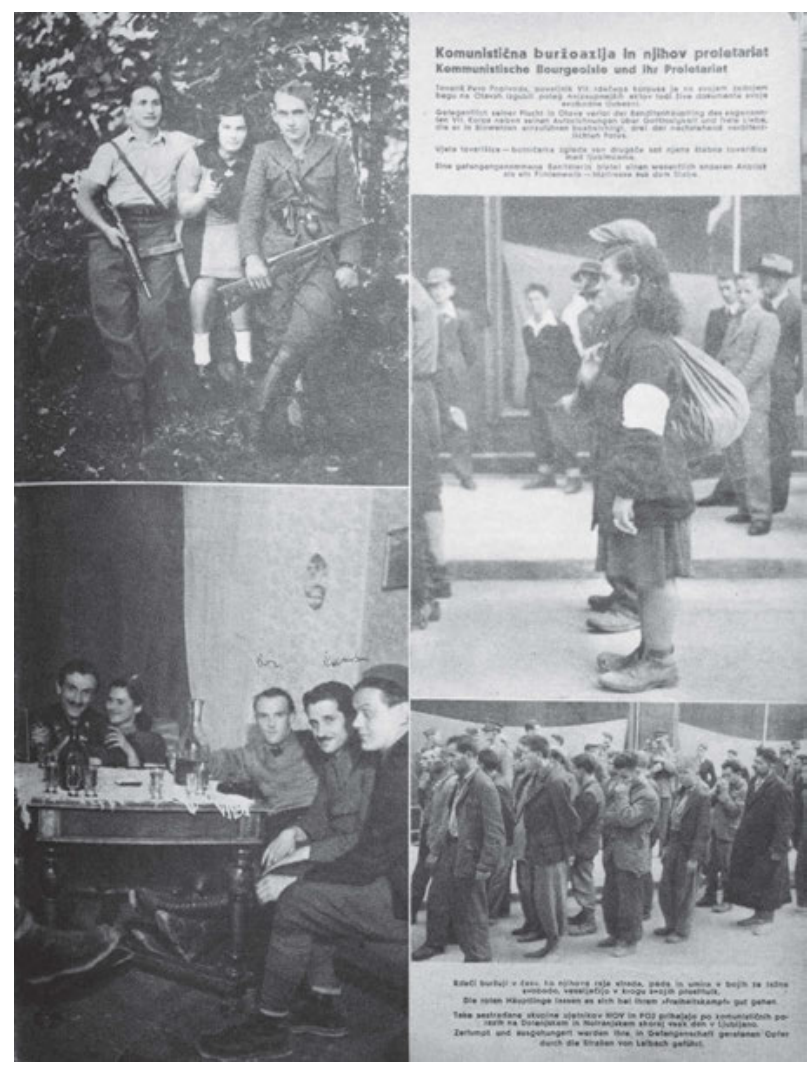

Slowenische Heimwehr Nr. 1. Ljubljana, Institut für neuere Geschichte. Ohne Inv.-Nr.

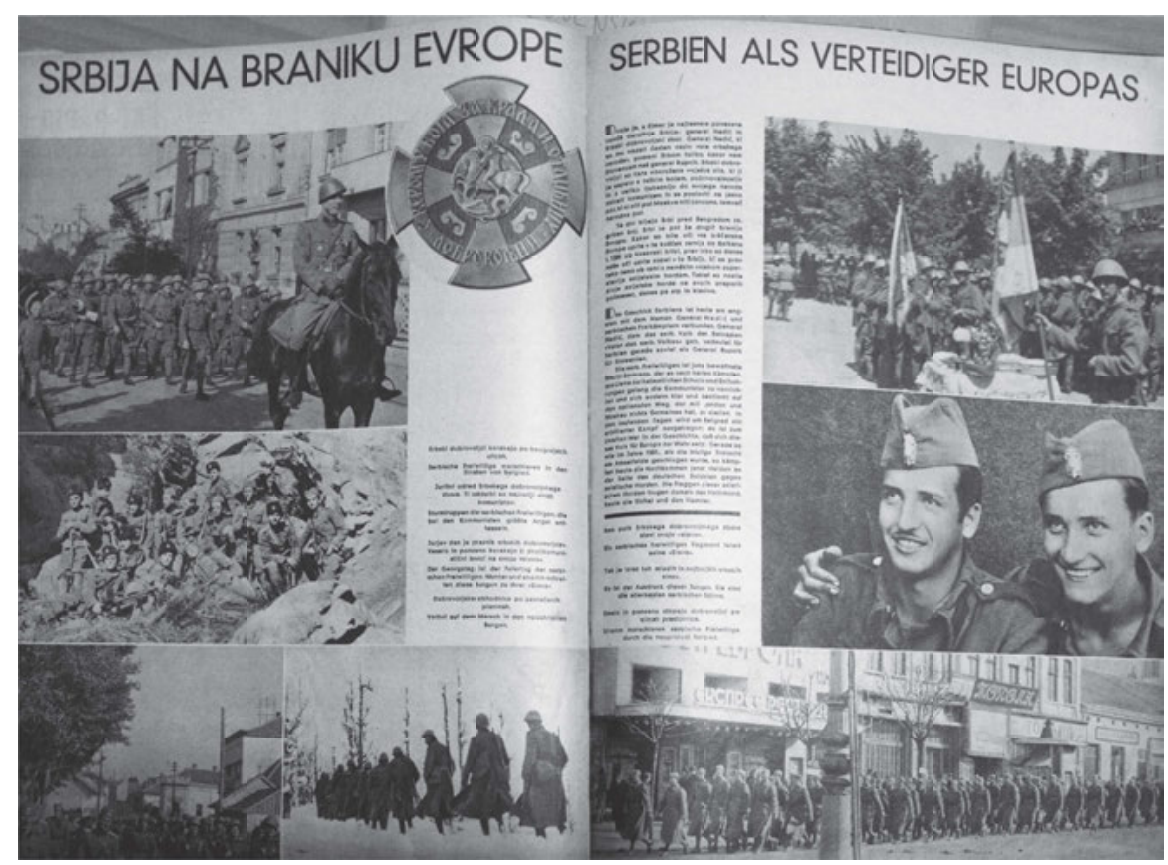

Doppelseite aus der Zeitschrift Signal. Undatiert. Ljubljana, Institut für neuere Geschichte. 


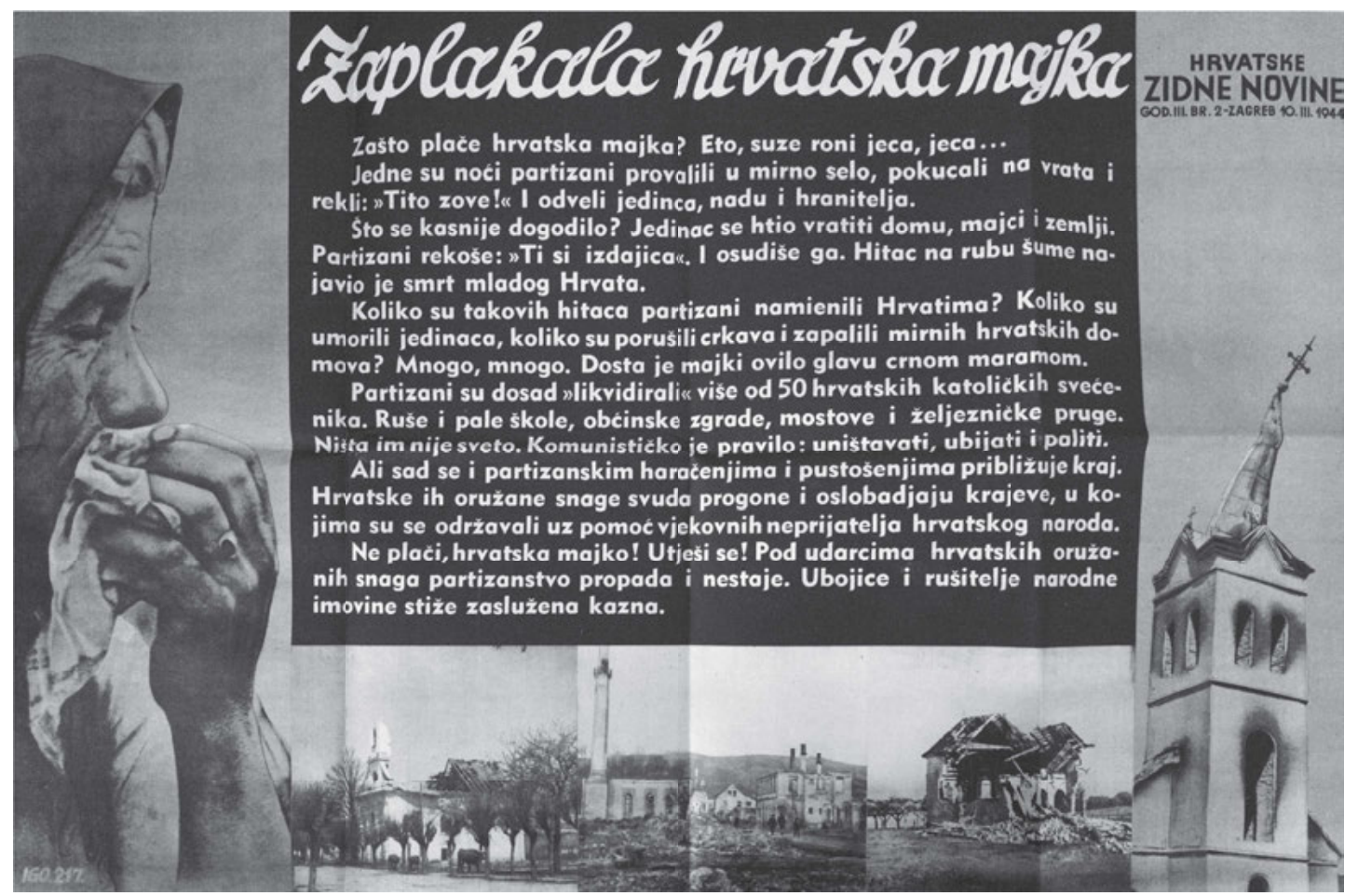

Plakat »Tränen einer kroatischen Mutter«. Sarajevo, Archiv von Bosnien und Herzegowina | FOND NDH

\section{Gründung der Nachrichtenagentur des Neuen Jugoslawien (TANJUG)}

Für die Propagandatätigkeit der Partisanenbewegung und für die Entwicklung des Fotojournalismus war die Gründung der Telegrafska agencija Nove Jugoslavije (Nachrichtenagentur des Neuen Jugoslawien) am 5. November 1943 von erheblicher Bedeutung. Ihre Gründung fand im Laufe der Vorbereitungen für die Zweite Sitzung des Antifaschistischen Rates der Volksbefreiung Jugoslawiens (AVNOJ) im bosnischen Städtchen Jajce statt. Als größter Befürworter der Agenturgründung erwies sich der angesehene Belgrader Maler Moša Pijade. Zum Direktor wurde Vladislav Ribnikar ernannt, Korrespondenten waren Milan Gavrić und Mahmud Konjhodžić, Radiotelegrafisten Veljko Dragićević, Jozo Butorac, Andjelko Gančević und Ante Runjić, Stenografen Aleksandar Tepavčević-Englez und Nikita Bakov, Übersetzerinnen Lepa Pijade, Olga Humo und Jara Ribnikar, Fotoreporter Danilo Kabić und Vili Šimunov-Barba. Letztgenannter nahm mit seiner Leica eine der ersten Fotografien der TANJUG-Redaktion auf. Abgesehen von Šimunov-Barba nennen einige Quellen auch den Berufsfotografen Ernst Grgić, der als Radiotelegrafist tätig war. Grgić hat als einer der ersten Bilder von Zuhörern der Agentur angefertigt, die zu jener Zeit Nachrichten in englischer und kroatisch-serbischer Sprache ausstrahlte. Der Agentur gelang es zudem, im September 1943, vermittelt durch Moša Pijade, von der Insel Vis aus fünf Fotografien zu schicken; für TANJUG bildete die Sendung einen technologischen Wendepunkt und den Übergang zum telegrafischen Versenden von Fotografien - einem Verfahren, das andere Agenturen bereits seit den 1930er-Jahren nutzten. Die Fotografien der Agentur TANJUG erschienen auf 
diese Weise erstmals in einer ausländischen Zeitung, der sowjetischen Zeitung Komsomolskaja pravda. ${ }^{34}$

Bereits ab dem 2. November 1941 strahlte die Radiostation Slobodna Jugoslavija (Freies Jugoslawien) unter der Direktion des Spanienkämpfers Veljko Vlahović ihr Programm aus, zuerst von Ufa im Ural, anschließend aus dem Gebäude der Kommunistischen Internationale in Moskau. ${ }^{35}$ Die Gründung der Agentur TANJUG war für die Entwicklung des Fotojournalismus von enormer Wichtigkeit, es wurden aber auch die organisatorischen Voraussetzungen für die Gründung eines professionellen Fotoreporterdienstes geschaffen. Neben der radiotelegrafischen Versendung von Nachrichten war vorgesehen, dass der Radiosender des Antifaschistischen Rates der Volksbefreiung Jugoslawiens sein Programm ausstrahlt, überdies wurden Fotoreportagen und Radioberichterstattungen angeboten, Ausstellungen organisiert, eine illustrierte Zeitschrift ins Leben gerufen und ein Reporternetzwerk aufgebaut. ${ }^{36}$ In der Agentur selbst gab es Kurse im Bedienen von mobilen Radiostationen, im Chiffrieren, in der Verwendung von Fotoapparaten und der Entwicklung von Filmen. ${ }^{37}$

Die Agentur hatte zudem die Aufgabe, die Partisanenbewegung weltweit zu repräsentieren, getragen von dem Bestreben, dass die von den Partisanen angeführte Volksbefreiungsbewegung trotz ihres kommunistischen und revolutionären Charakters als einzige antifaschistische Bewegung auf dem Territorium Jugoslawiens anerkannt wird. Im Rahmen der Zweiten Sitzung des AVNOJ in Jajce 1943, auf der die Grundlagen für die künftige Gesellschaftsordnung des neuen Staates geschaffen wurden, entstand somit die Agentur TANJUG, die zu einer der wichtigsten und professionellsten Nachrichtenagenturen Mittel- und Südosteuropas aufsteigen sollte. Ihr Untergang begann in den 1990er-Jahren, als sie gänzlich unter die Kontrolle des Regimes von Slobodan Milošević fiel. Heute steht sie unmittelbar vor der Einstellung.

Bald nach ihrer Gründung stießen geschulte Fotografen zur Agentur, zum Beispiel Stevan Benčić und Branko Savić, der das fotografische Handwerk in Deutschland erlernt hatte und dessen Vater einen Fotoladen im Belgrader Stadtzentrum besaß. ${ }^{38}$ Zu Savićs Werk zählen unter anderem Fotoreportagen, die bei der Befreiung des Lagers Jasenovac entstanden. Diese zwischen 1944 und 1947 entstandenen Bilder werden auf mehreren Dutzend Filmnegativen in der Agentur TANJUG verwahrt. Vermutlich hatte das einstige Marschallamt von Josip Broz Tito diese Negative zusammen mit den Kontaktkopien der Agentur TANJUG übernommen, da in jeder Schachtel der Kontaktabzüge besonders gekennzeichnete Filmnummern mit einem Bild von Tito zu finden sind, wie die Mitarbeiter des Museums Jugo-

34 Huljić, Veseljko. Vis 1941-1945. Split: Institut za historiju radničkog pokreta Dalmacije 1979, S. 268.

35 Roberts, Valter. Tito, Mihailović i saveznici 1941-1945. Belgrad 2013: Čigoja štampa, S. 82.

36 Huljić, Veseljko und Dželebdžić, Milovan. Veze u Narodnooslobodilačkoj borbi 1943.-1945. Bd. II. Belgrad: Vojnoizdavački zavod 1984, S. 145; Ćemalović, Enver. Mostarski bataljon. Mostar: Skupština opštine Mostar i Odbor za istoriju revolucionarnog radićkog pokreta i NOB-a Mostara 1986, S. 163.

37 Marić, Mihajlo. Fragmenti iz okupiranog Beograda. In: Tihić, Esad und Kalem Momčilo (Hrsg.). Veze u NOB-u 1941-1945. Ratna sećanja. Bd. V. Belgrad: Vojnoizdavački zavod 1981, S. 127.

38 Rovčanin, Snežana. Kvadrati filma spojili i most. In: Večernje novosti, 07.05.2007. Siehe http://www.novosti.rs/vesti/naslovna/reportaze/aktuelno.293.html:197712-Kvadrati-filma-spojili-i-most [Abruf am 02.02.2021]. 


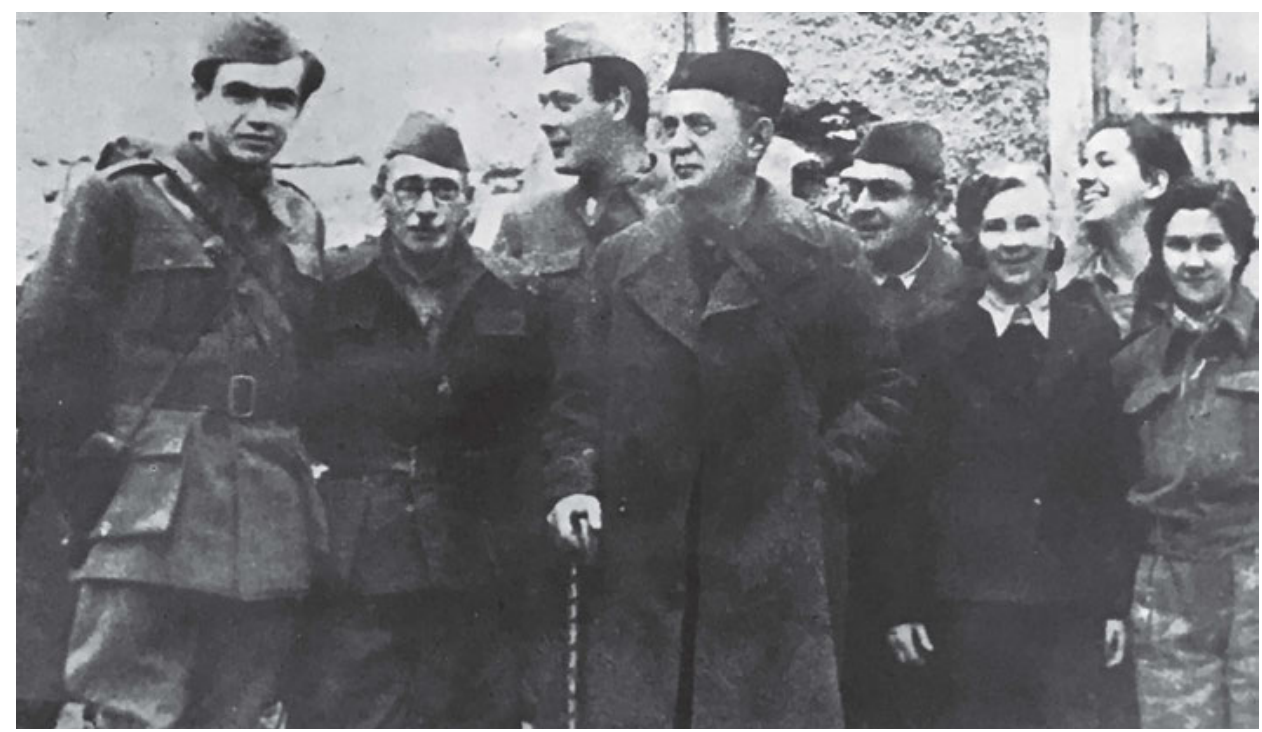

Erste TANJUG-Redaktion. Von links nach rechts: Ivo Lola Ribar, Moša Pijade, Vladimir Velebit, Ivan Ribar, Vladislav Ribnikar, Lepa Pijade, Olga Humo und Jara Ribnikar. Fotograf unbekannt. Aus: Aleksić, Dejan (Hrsg.). Tanjug 1943-1963. Belgrad: Novinska agencija TANJUG 1963, S. 7.

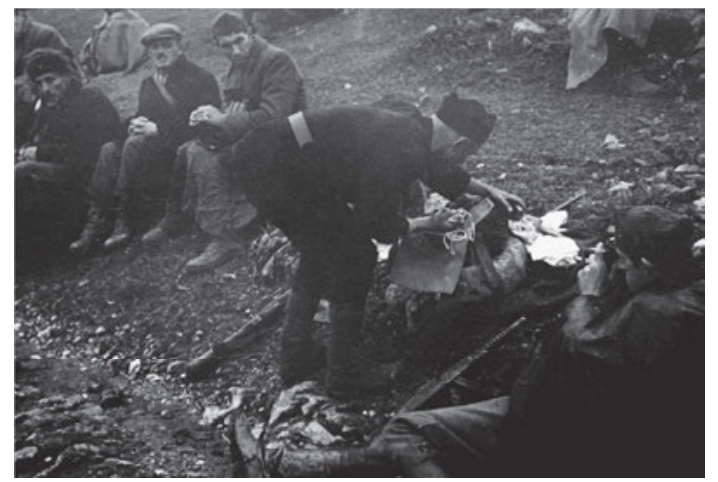

Delegierte auf ihrem Weg zum Zweiten Kongress des Antifaschistischen Rates zur Volksbefreiung Jugoslawiens. Von rechts nach links: Otmar Kreačić-Kultura, Dr. Pavle Gregorić. Fotograf unbekannt. Belgrad, Museum Jugoslawiens | III-274.

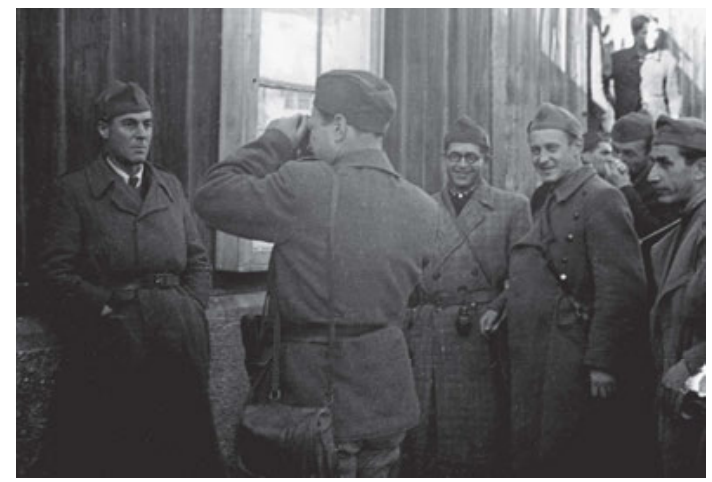

Der Fotograf Vili Šimunov-Barba fotografiert Delegierte beim Zweiten Kongress des Antifaschistischen Rates zur Volksbefreiung Jugoslawiens. Fotograf unbekannt. Belgrad, Museum Jugoslawiens | III-274.

slawiens in Belgrad erst kürzlich entdeckt haben. In vorliegendem Buch wird ein Teil dieser Aufnahmen von Branko Savić, Isak Koen und Pavle Obradović zum ersten Mal veröffentlicht. Viele Jahre nach dem Krieg erzählte Branko Savić über die Befreiung von Jasenovac:

"Vier waren noch am Leben. Sie krochen entlang der Wand der Ziegelei, als Schüsse in der Nähe zu hören waren. Sie konnten sich retten. Ich fotografierte so lange, bis alle Filme aufgebraucht waren [...]. Die Save zog sich zurück. Aneinandergekettet - Menschen. Alle tot. Jeweils 15-20 in einer Reihe. Und als ich dachte, dass das Ganze zu Ende sei, kam es zu neuen Massakern. Man ertränkte sie lebend. Als sich das Wasser zurückzog, konnte man alles sehen. $\aleph^{39}$ 


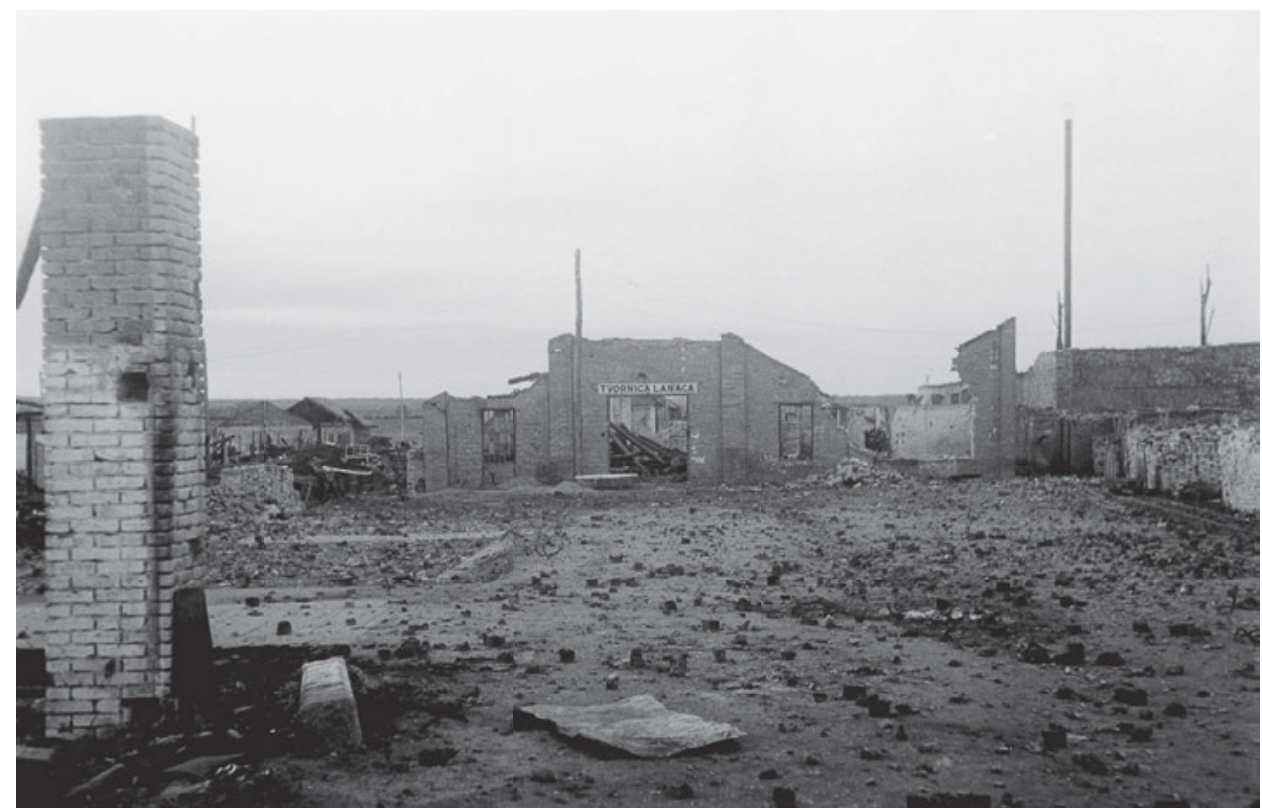

Überreste des Konzentrationslagers Jasenovac, von der Ustascha beim Rückzug weitgehend zerstört. 5. Mai 1945. Fotograf: Branko Savić. Belgrad, Museum Jugoslawiens | VIS 28604.

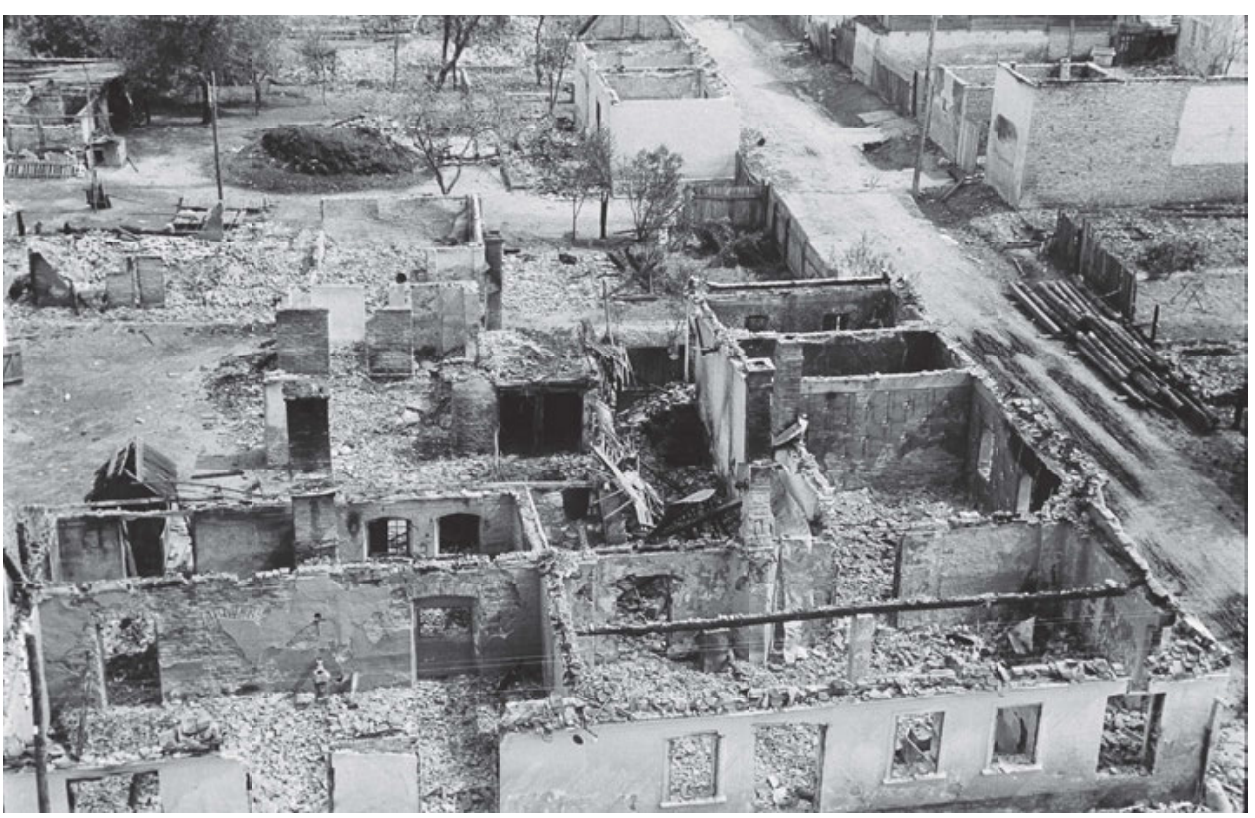

Zerstörung des Dorfes Jasenovac, aufgenommen vom Dach der katholischen Kirche, 5. Mai 1945. Fotograf: Branko Savić. Belgrad, Museum Jugoslawiens | VIS 28614. 


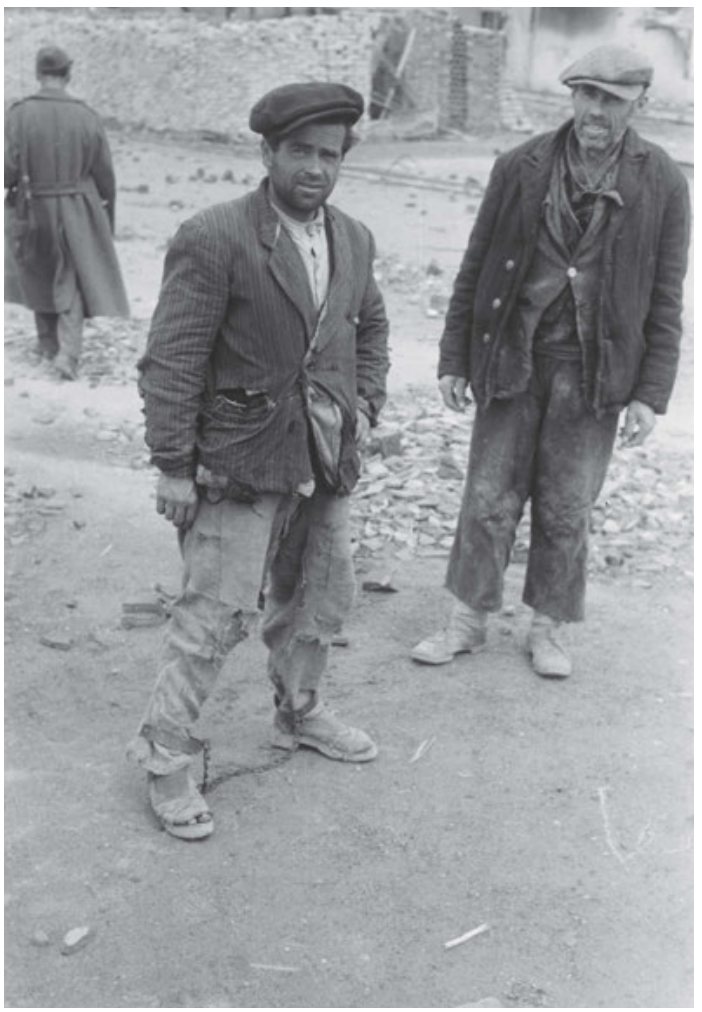

Ehemalige Häftlinge des Konzentrationslagers Jasenovac, 5. Mai 1945. Belgrad, Museum Jugoslawiens | VIS 28621.

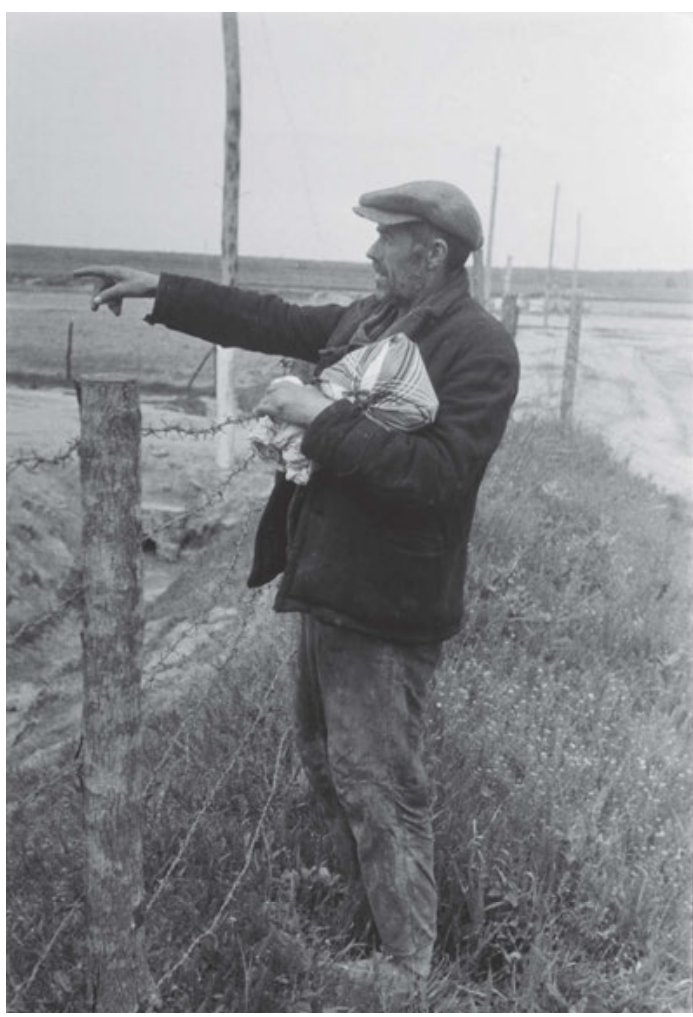

Augenzeuge vor dem Konzentrationslager Jasenovac. Belgrad, Museum Jugoslawiens | VIS 28626.

Zur gleichen Zeit fotografierte auch Mato Tačković, ${ }^{40}$ Mitglied des Fotodienstes des Bezirksrates der Volksbefreiung Slawoniens, das Konzentrationslager Jasenovac, nachdem er es mit den Soldaten der 28. Slawonischen Division am 24. April 1945 betrat.

Das Schicksal der restlichen Negative von Savić ist bis heute unbekannt, doch kann man davon ausgehen, dass die Bilder aus der gleichen Zeit wie die hier gezeigten Fotografien stammen. Alle Kommandanten der Korps erhielten die strikt einzuhaltende Weisung, zusammen mit den Kommissionen für Kriegsverbrechen Daten über die Lager Jasenovac, Slavonski Brod, Savska cesta, Djakovo, Slavonska Požega und Feričanci zu sammeln, direkt nach der Befreiung der Orte Aufnahmen zu fertigen und diese der Landeskommission für die Ermittlung von Kriegsverbrechen zuzuschicken. ${ }^{41}$ Die Fotografien stechen durch ihre technische und fotografische Qualität heraus und lassen sich mit dem hohen Niveau der Arbeit der Alliierten vergleichen. Davon zeugen auch die Bilder der Befreiung von Zagreb, die ebenfalls im vorliegenden Buch zum ersten Mal veröffentlicht werden.

39 Ebd.

40 Mihovilović, Djordje. Jasenovac 1945-1947. Fotomonografija. Jasenovac: Javna ustanova Spomen područje Jasenovac 2016, S. 18.

41 Zbornik dokumenata i podataka o narodnooslobodilačkom ratu jugoslovenskih naroda. Bd. V/34: Borbe u Hrvatskoj 1944. godine. Belgrad 1966. 


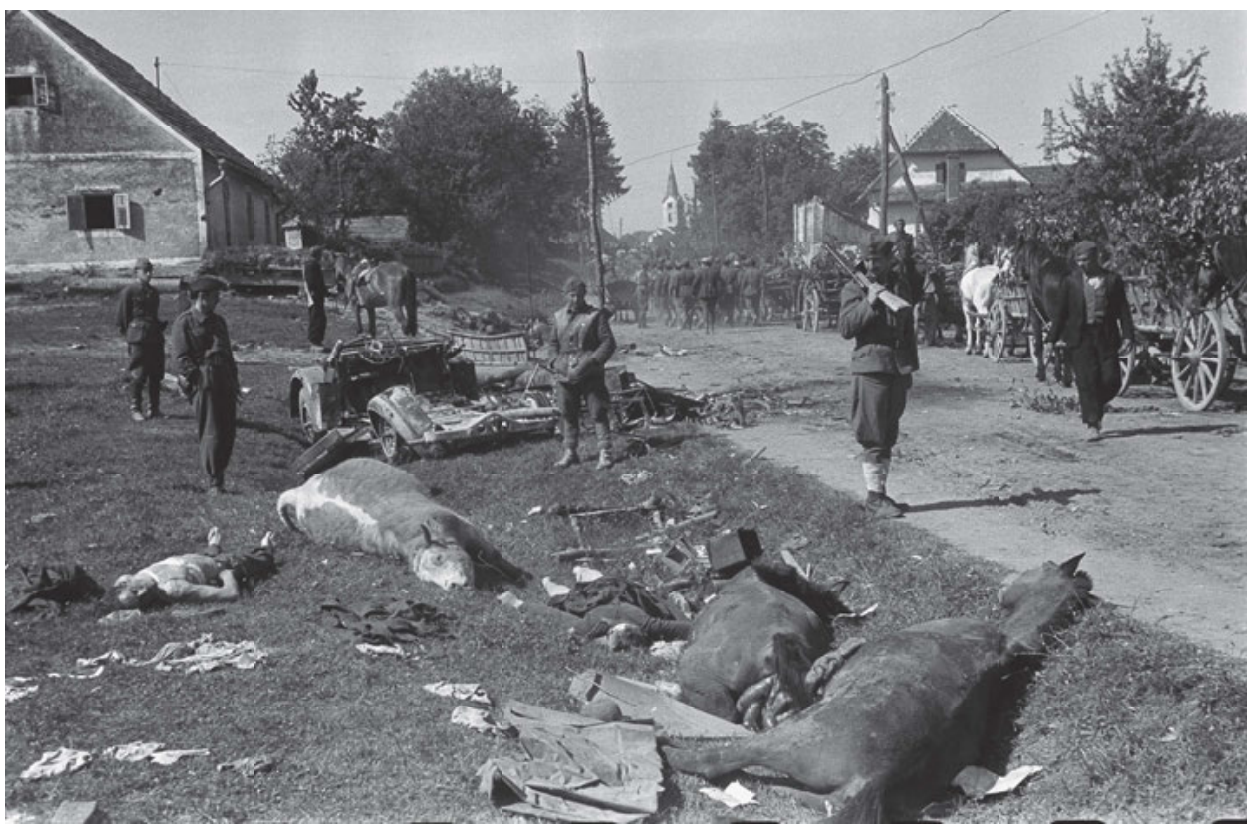

Vormarsch der Jugoslawischen Armee in Zagreb, Mai 1945. Belgrad, Museum Jugoslawiens | VIS 2870.

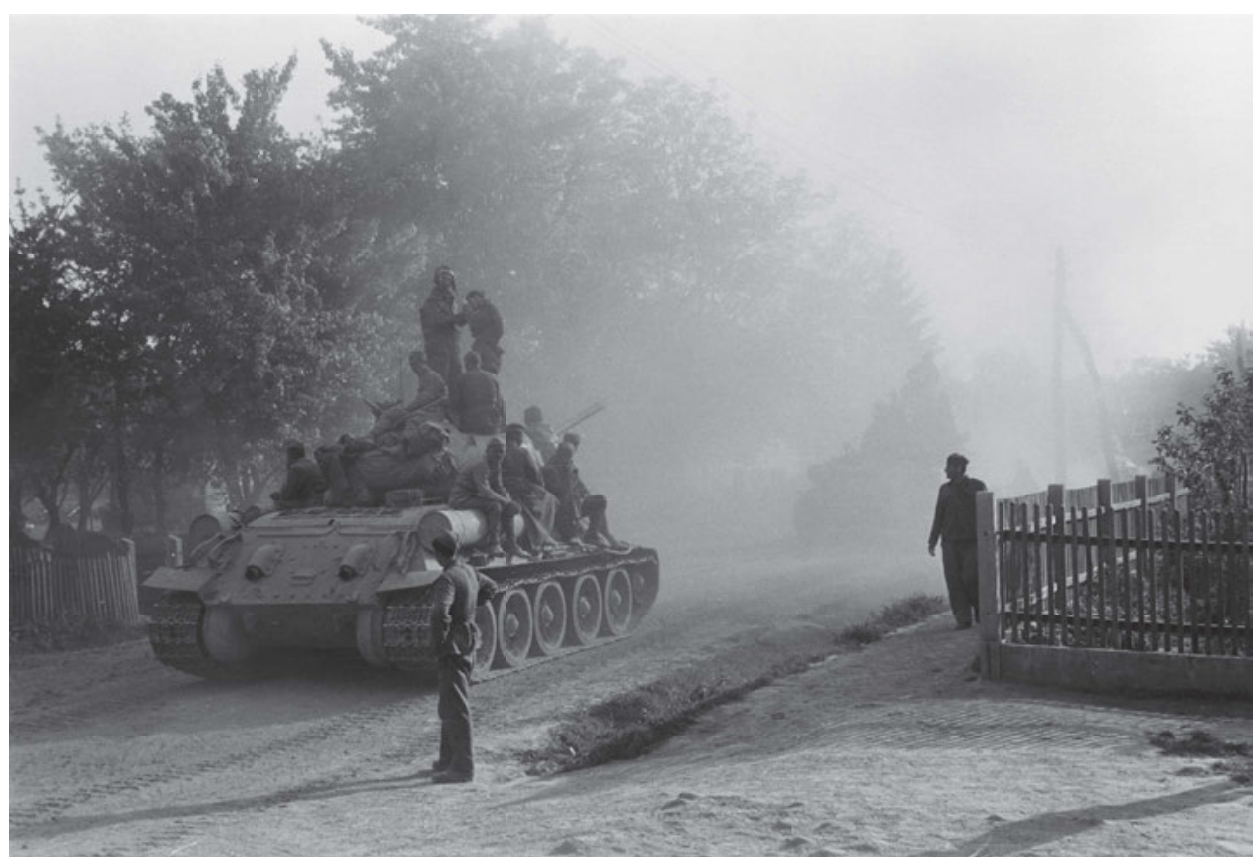

Vormarsch der Jugoslawischen Armee in Zagreb, Mai 1945. Belgrad, Museum Jugoslawiens | VIS 28819. 


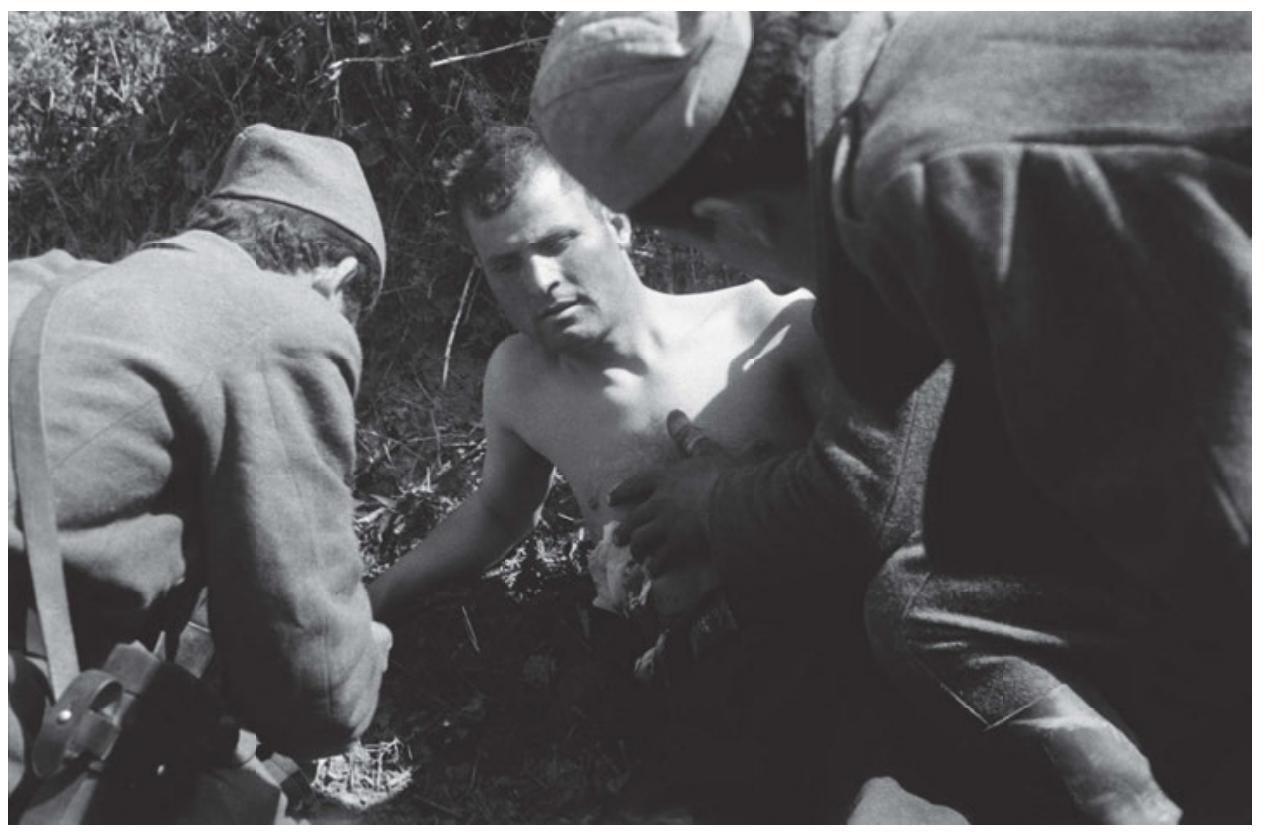

Vormarsch der Jugoslawischen Armee in Zagreb, Mai 1945. Belgrad, Museum Jugoslawiens | VIS 2890.

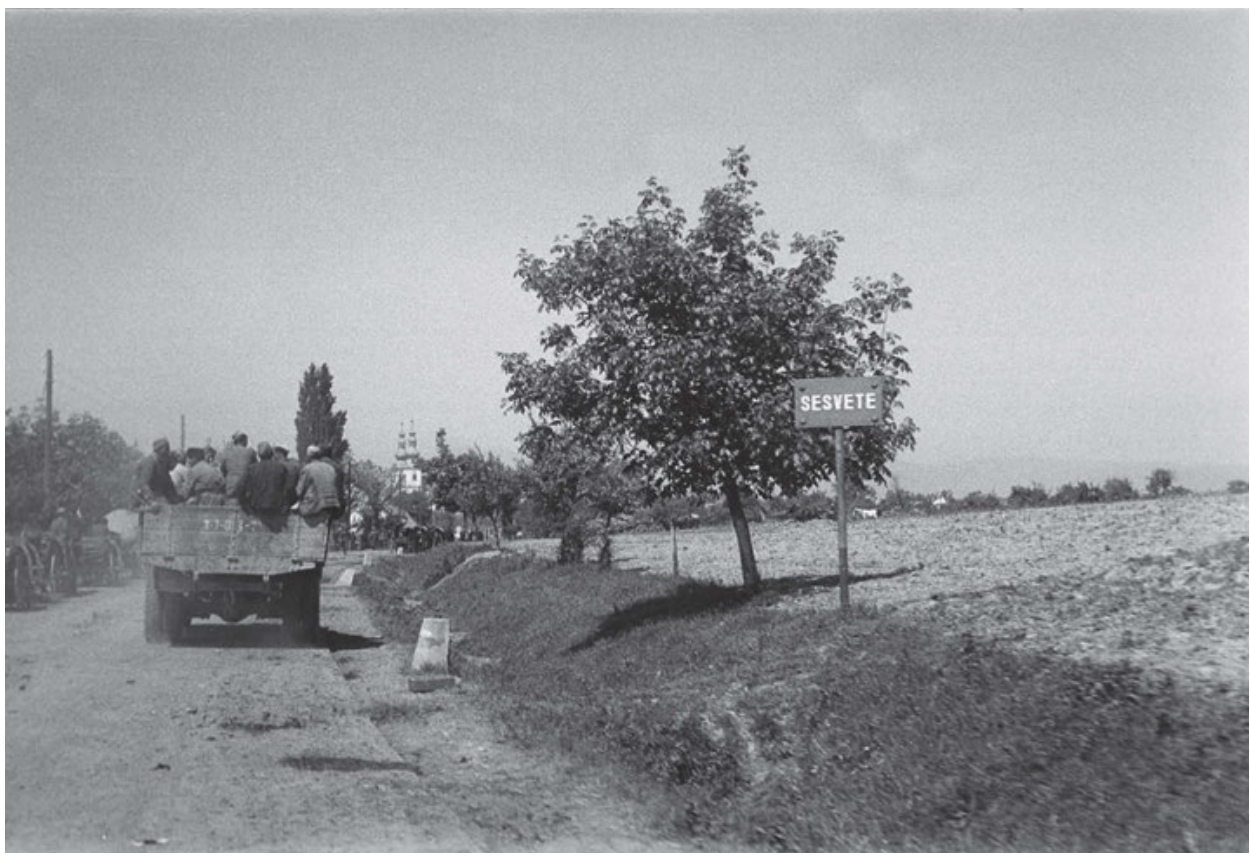

Vormarsch der Jugoslawischen Armee in Zagreb, Mai 1945. Belgrad, Museum Jugoslawiens | VIS 28922. 


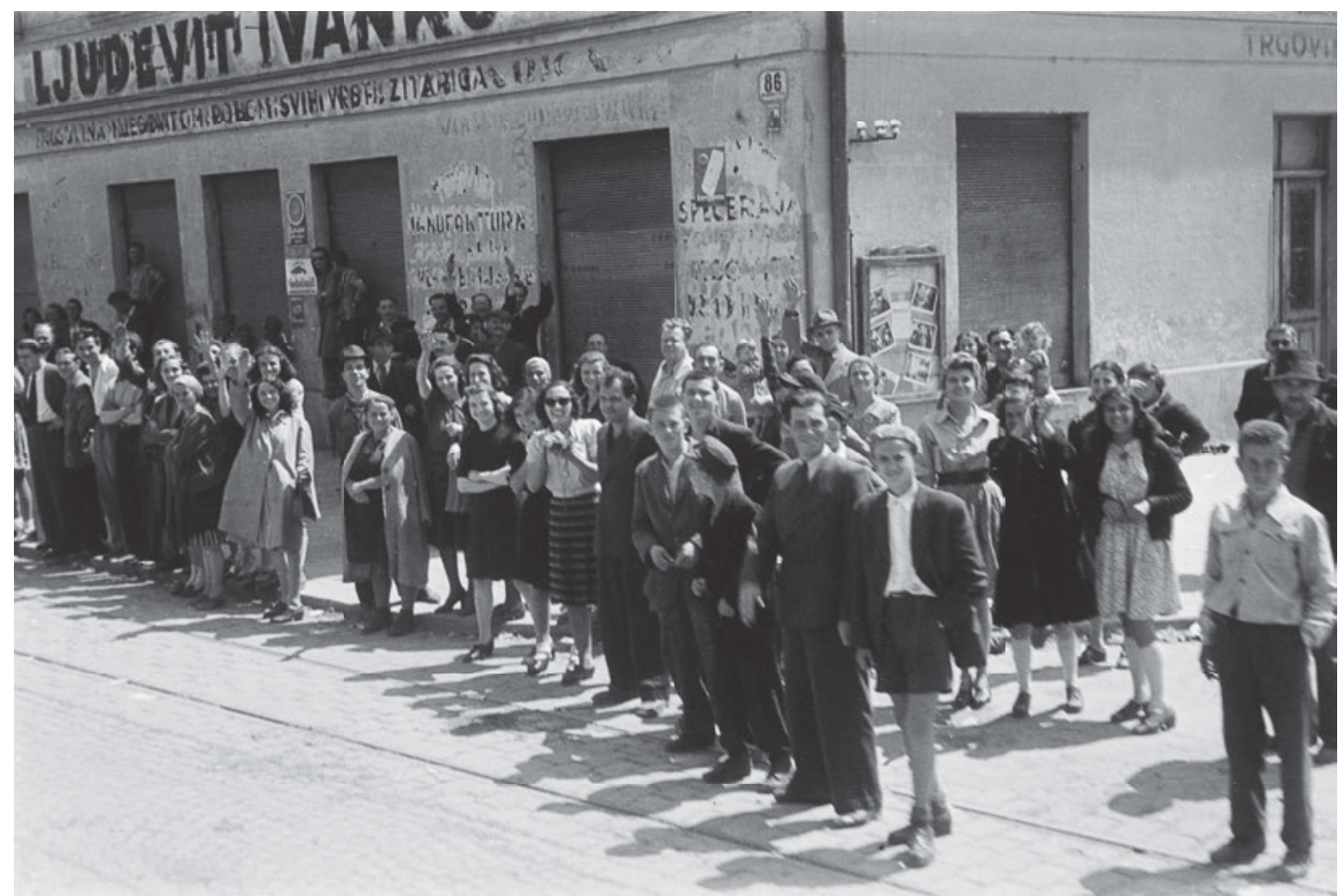

Ankunft der Jugoslawischen Armee in Zagreb, 8. Mai 1945. Belgrad, Museum Jugoslawiens | VIS 29012.

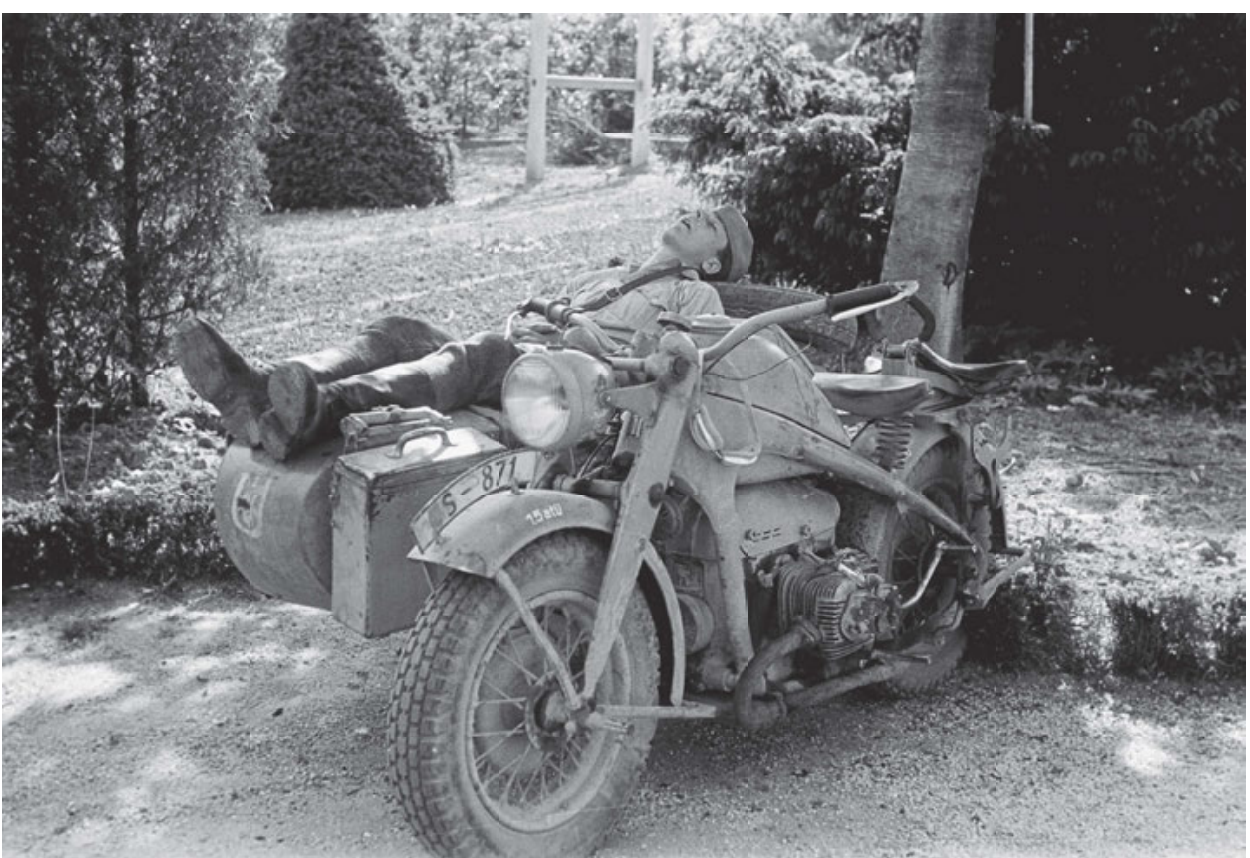

Ankunft der Jugoslawischen Armee in Zagreb, 8. Mai 1945. Belgrad, Museum Jugoslawiens | VIS 29123. 


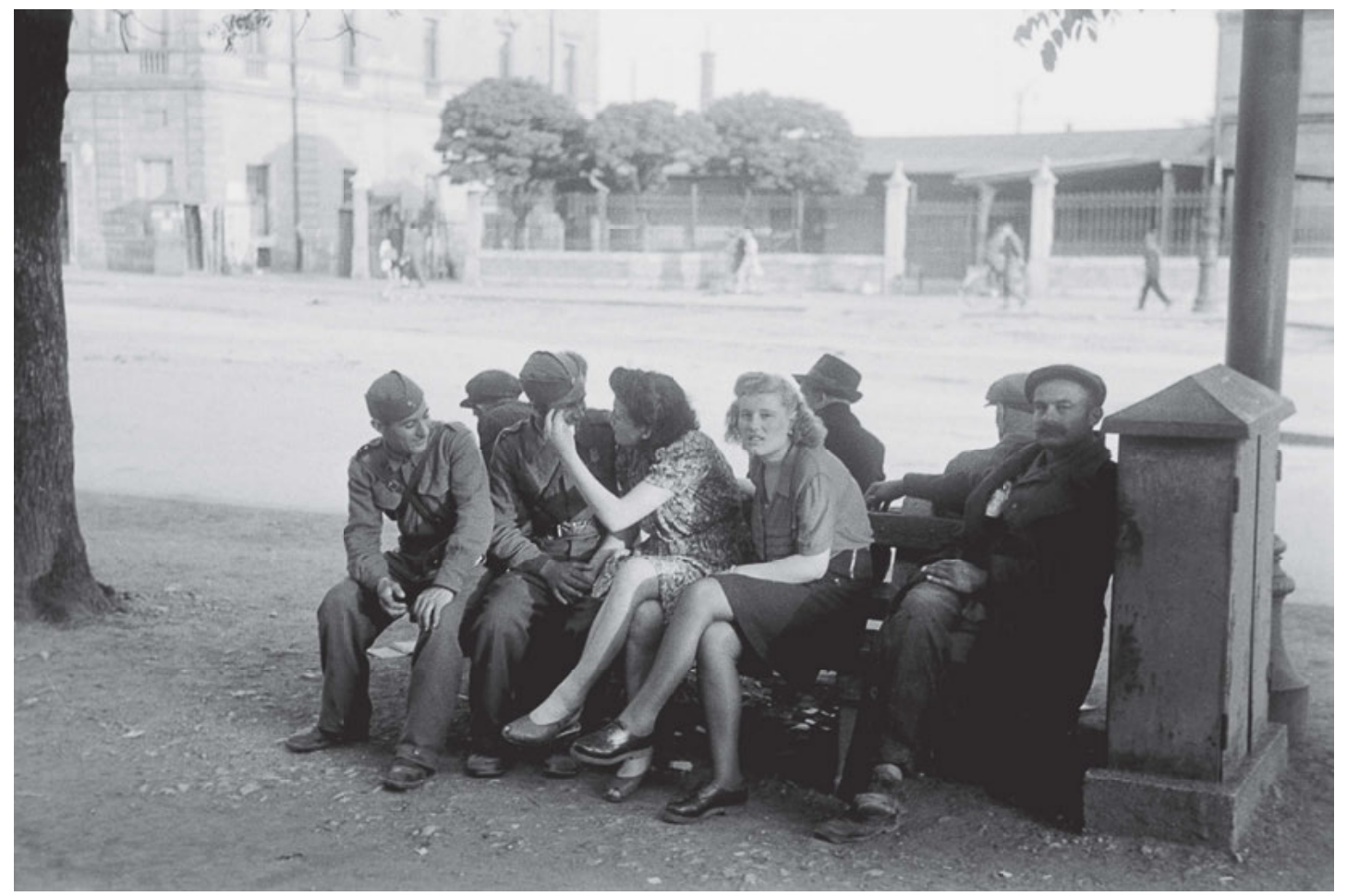

Ankunft der Jugoslawischen Armee in Zagreb, 8. Mai 1945. Belgrad, Museum Jugoslawiens | VIS 29135.

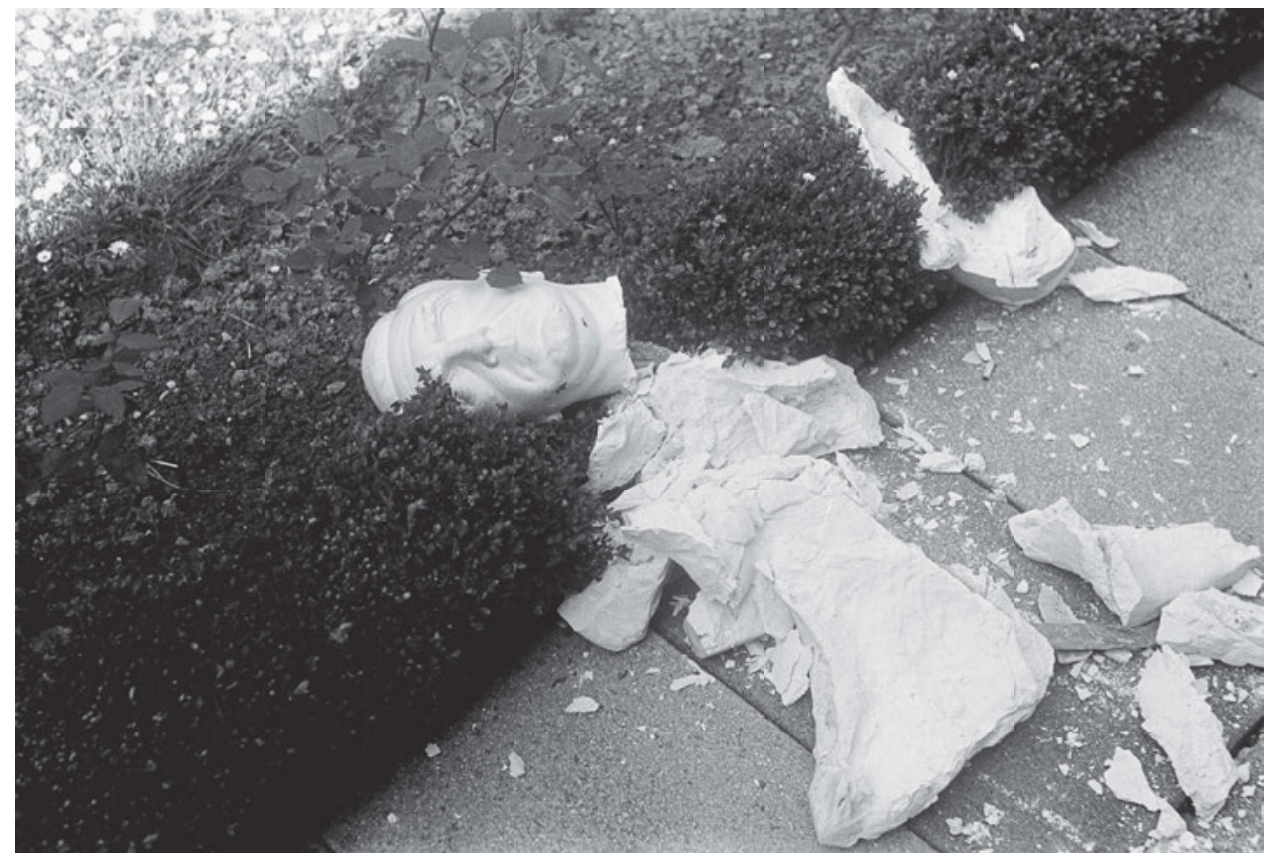

Zerstörte Statue des Ustascha-Führers Ante Pavelić, unmittelbar nach Befreiung der Stadt Zagreb, Mai 1945. Belgrad, Museum Jugoslawiens | VIS 29335. 


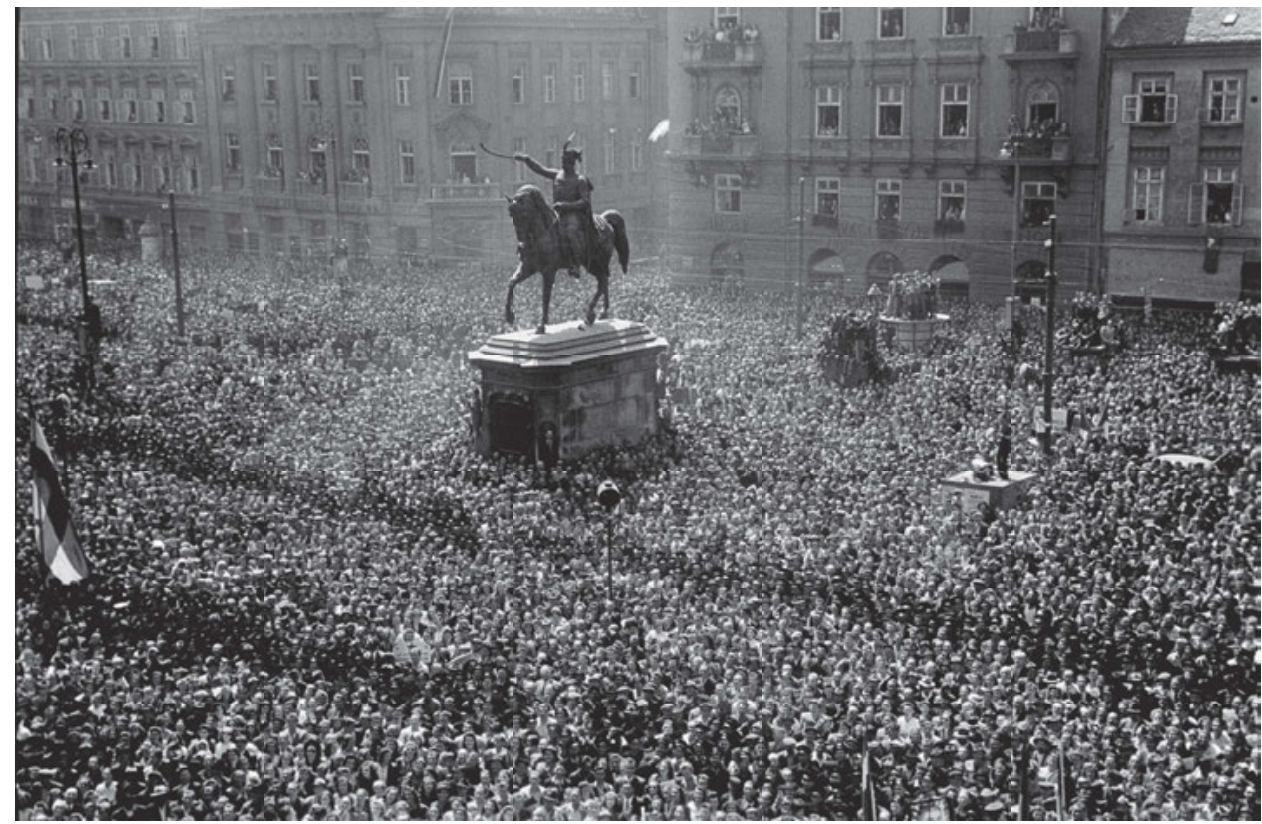

Versammlung in Zagreb anlässlich der Befreiung und des Kriegsendes, 11. Mai 1945.

Belgrad, Museum Jugoslawiens | VIS 29213.

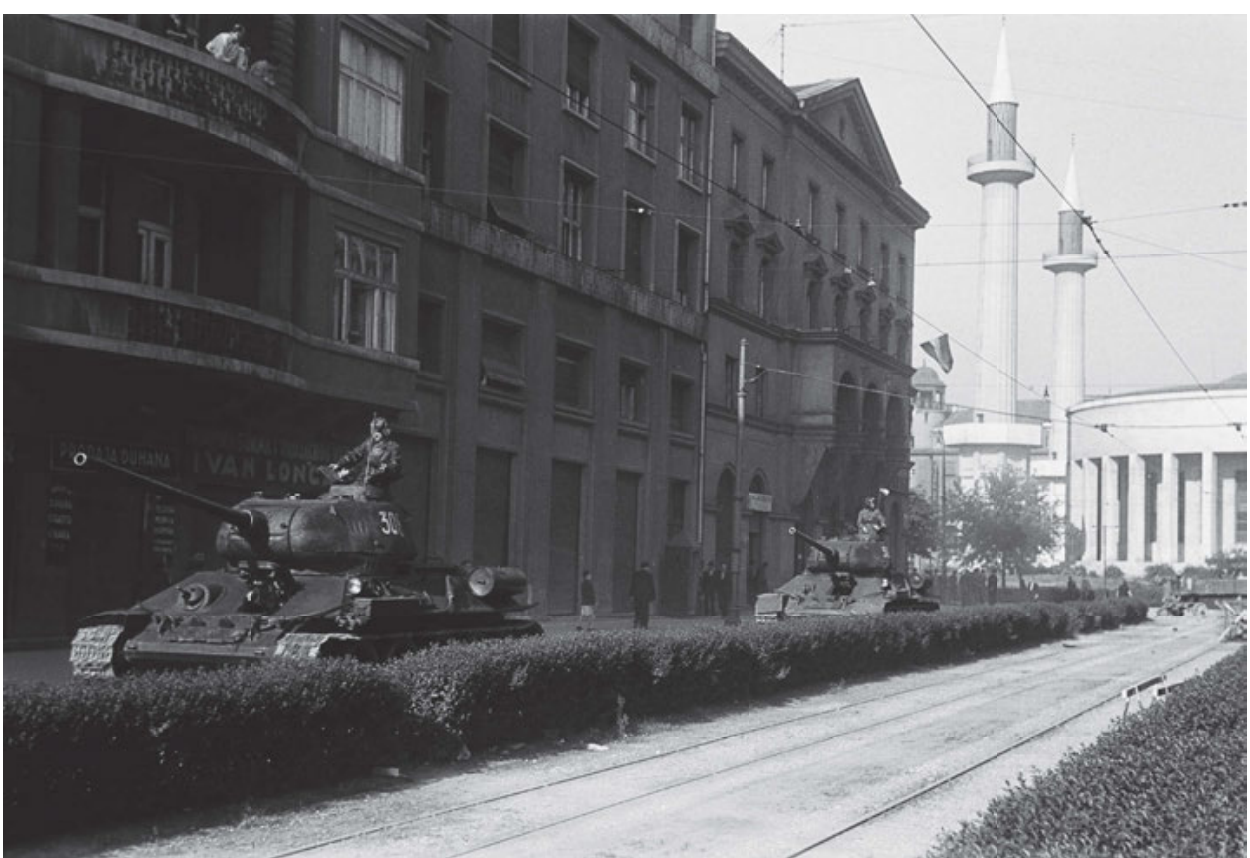

Parade der jugoslawischen Armee im befreiten Zagreb, 13. Mai 1945.

Belgrad, Museum Jugoslawiens | VIS 29612. 


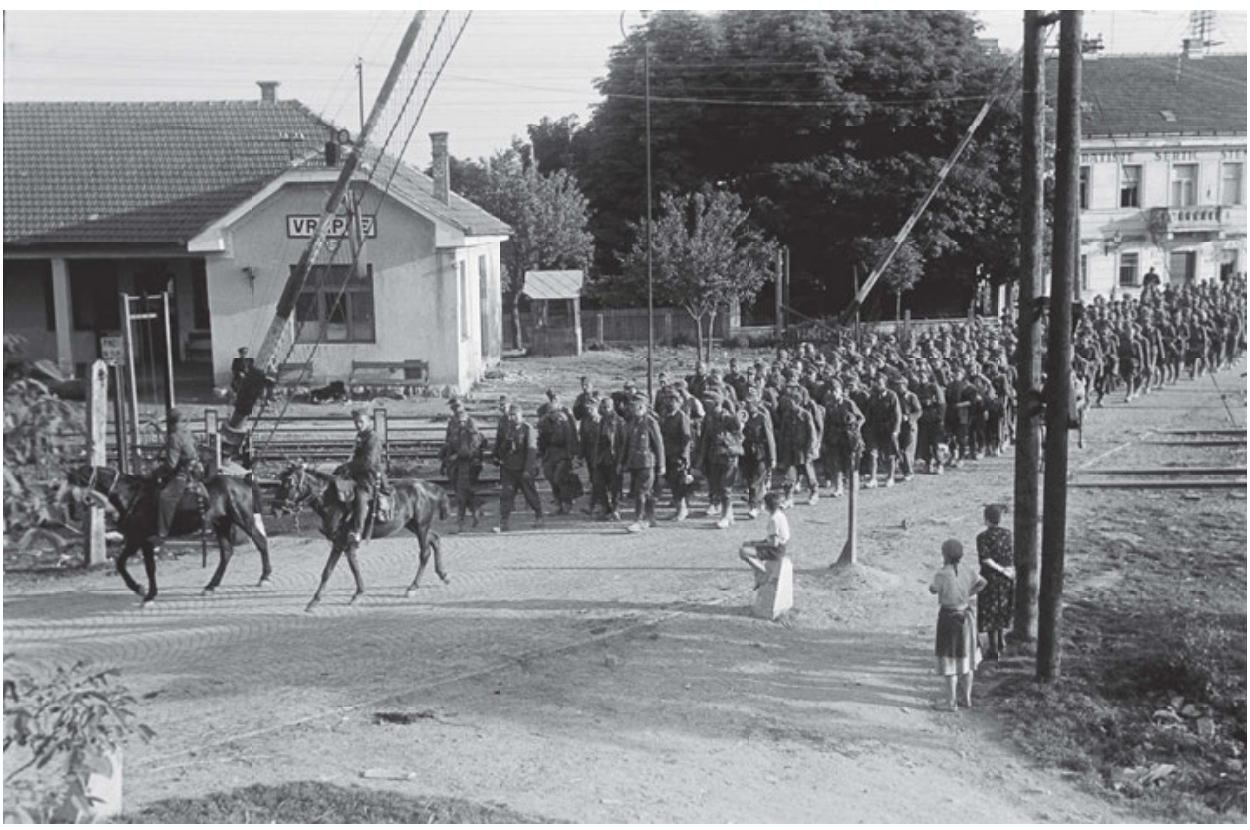

Gefangene feindliche Soldaten in Zagreb, Mai 1945. Belgrad, Museum Jugoslawiens | VIS 29424.

\section{Über die Unmöglichkeiten der Propaganda}

Ungeachtet der Befehle und der fortschreitenden Organisierung des Propagandaapparats unterlag die Tätigkeit der Fotografen weiterhin nicht der zentralisierten Propagandakontrolle. Eine Vielzahl von Fotografen entwickelte ihre Filme selbst, ohne Aufsicht durch die Propagandaabteilungen, die ohnehin oftmals die Entscheidungen den Fotografen überließen, auch wenn sie die Möglichkeit hatten, auf ihre Arbeit Einfluss zu nehmen. In den meisten Berichten ist zu lesen, dass Erfolge in der fotografischen Arbeit erzielt worden sind, doch als limitierender Faktor wurden stets die schlechten technischen und produktionstechnischen Bedingungen sowie Personalmangel genannt. Der eigenen Intuition und Vision folgend, nahmen die Fotografen jene Motive auf, die sie selbst für wichtig hielten, während es den Propagandisten chronisch an Fotos der unmittelbaren Kämpfe fehlte - sogar im letzten Kriegsjahr, worüber im Bericht des Neunten Korps Folgendes geschrieben steht:

»Es fehlt uns an Material für Negative und Positive, insbesondere jedoch an geschickten Fotografen und Fototechnikern. Die Zahl der Fotografien der unmittelbaren Kriegshandlungen steht bei Weitem hinter den Fotografien zurück, die vorher oder nachher angefertigt wurden. Die Zahl der unter Wagnissen aufgenommenen Fotografien ist immer noch zu gering. Die Fotosektion ist so sehr durch die tägliche Arbeit belastet, dass sie einfach nicht imstande ist, ältere Bilder in größeren Zahlen zu reproduzieren. « ${ }^{42}$ 
Es wurden zudem Kritiken laut, dass die Filme nicht rechtzeitig in den Einheiten einträfen oder zweckentfremdet würden. In den Weisungen der Abteilung für politische Bildung der 26. Stoßdivision vom 4. April 1945, die an die Abteilungen für politische Bildung der ihr untergeordneten Brigaden gerichtet waren, wurde kritisch resümiert, dass Filme für Aufnahmen irgendwelcher Kolonnen, Porträts oder führender Persönlichkeiten verwendet werden:

»Bis heute hat keine einzige Brigade Fotografien, Artikel oder Biografien namhafter Kämpfer oder Anführer eingeschickt, die im Kampf gefallen oder noch am Leben sind. [...] Man sollte nicht denken, dass der Fotograf eine Exklusivität der Brigade sei, dies ist nicht nur für die Brigaden von Bedeutung, sondern für unsere gesamte Armee! Wenn die Filme entwickelt werden, wird all das, was gut ist, für unsere zentrale Propaganda produziert werden: für die Armee, Divisionen, ja auch für Brigaden, die Ausstellungen zur Geschichte der Brigade oder zu einem ähnlichen Thema organisieren könnten. Jene Fotografien, die nicht von wesentlicher Bedeutung sind, werdet ihr als originale Kopie samt Negativ für das Archiv zurückbekommen. Die wichtigsten werdet ihr im Format $13 \times 18$ erhalten. In den Brigaden sind sinnlose Aufnahmen zu verbieten, mit denen nur Material unnütz verschwendet wird. Fotografieren soll man nur dann, wenn damit ein propagandistisches Ziel verfolgt wird, nämlich wenn es sich um Aufnahmen eures Kampfes, bedeutender politischer und kultureller Momente sowie der freudigen Begegnungen mit dem Volk handelt, welches befreit wird usw. «43
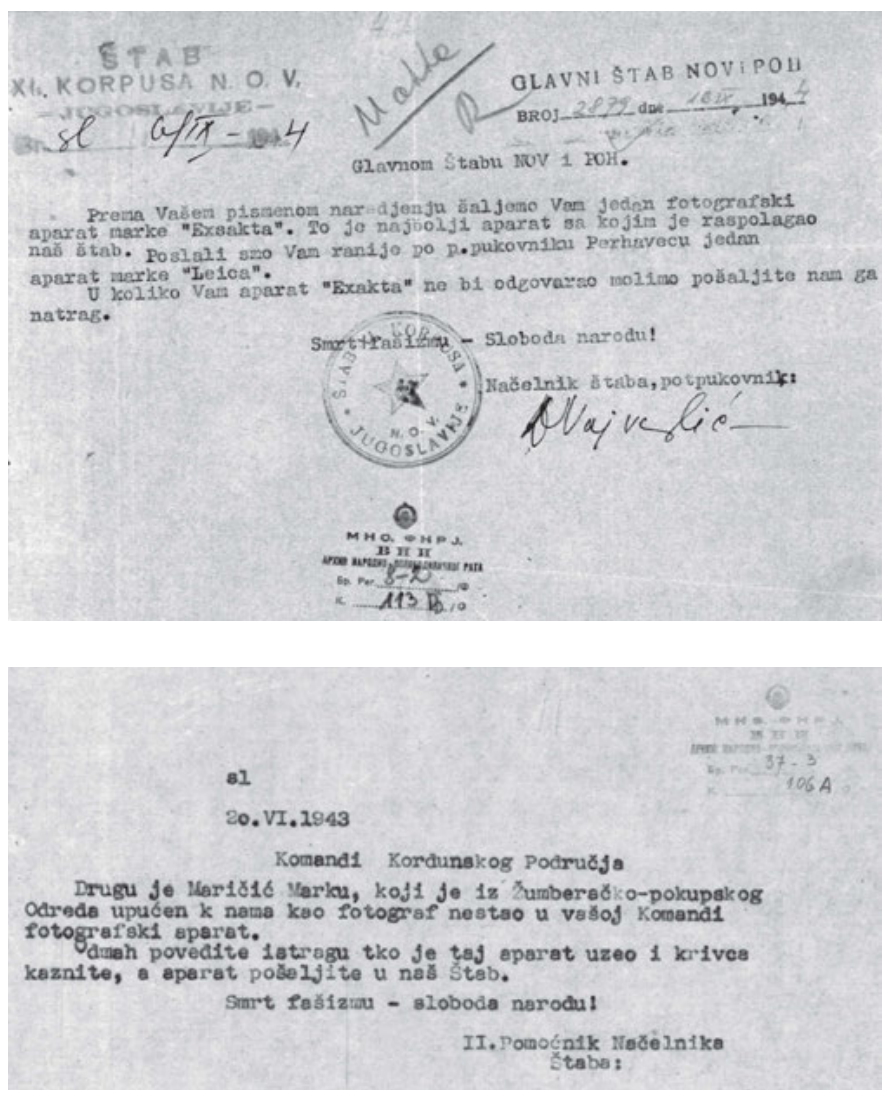

Meldung über das Verschwinden eines Fotoapparates. Belgrad, Militärarchiv | NOVJ K113B F2 8.

\author{
Meldung über \\ das Verschwinden \\ eines Fotoapparates. \\ Belgrad, Militärarchiv | \\ NOVJ K113B F2 8.
}


ITАБ VII ВОЈВОВАНСКВ БРИГАДЕ

Народно-Ослободи мачкө во јскө

Jy госла ви је

Бро j: Сауво өно

Дана 4-XI-1944 год.

Пор доваj

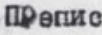

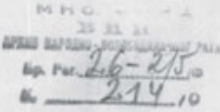

\section{Друже Чамо,}

Фото-репортөр наше Бригеде Лаза, незнем му прөзиме, већ неко акко дана се нө јеве овок штебу, што нас је нагнело де ге сотрекимо. Јучө ге је сасвим сдучајно пронашво помоћник кокесере бригеде у грађенској куkи у cоби аяменика коментанданта мөста. На питаве овога шта он ту ради он јө дао овако сиянан одговор. Ја сам друже кокөсару на боловану, добио сам дужност көо први помоһник коканданте кеста. 0 свеку овокө

Овеј штеб дотле ни и неянако кеко се когло догодити да му болница ияда уверевө на три месеце болозана. Кад он уопштө није болестан. А како се додворио у команду щөств

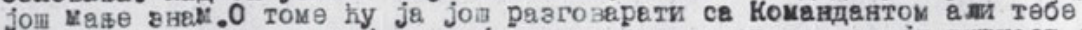
обавентевек внева ради јер он јө сада прөстао вршити сво ју дужност, соторөпортөрн, па га ти пронаьи и одузии ку апарат.

Пази ти тог шпекулантв, како симом вели постати нөки грађански

уцравник. Он јө како чу јек пришио поручничке анакө.Назнак ко му јө тө

әнаке дао и да ди он неквд био поручник. Одмех иу реди де скине анакә

пошто ја неңу имати времөн, де будек са вим.

Молим тө учни крај са глупостима која чини тај човек.

Да аи су готовө саике које си сникиоонеј ден?

\section{Сирт фашиаку - Сдободе нероду!}

$$
(\mathrm{n}, \mathrm{n} \cdot)
$$

С другарскии поздравок

$4-X I-1944$ год.

Комесар VII Војво јанскө бригедө. дазар цубивковић с.P.

Да јө овеј прөпис веран своме оригинаду који се налази код

Прспегендног отсеке Гші, тВРди: Пропегандни отсек Гші

Нови Сед, 10 новембра -1944 год. Cхрг сешияку - Спободе народу!

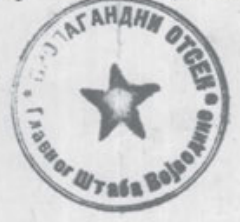

Мөф Пропагендног отсөке:

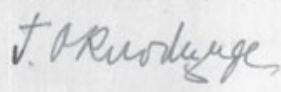

Nachricht über eine angebliche Krankmeldung eines Fotoreporters der Siebenten Vojvodina-Brigade, mit der Bitte, ihm den Fotoapparat wegzunehmen. Belgrad, Militärarchiv | NOVJ K214 F5 26.

Aufschluss über das fotografische Fachwissen in den einzelnen militärischen Einheiten gibt auch ein Bericht zur Arbeit der Fotografie- und Filmsektion in der Fünften Serbischen Stoßbrigade der Volksbefreiung:

»Die Sektion zählte drei Mann, wobei Ende Februar 1945 noch zwei weitere Fotografen hinzukamen. Wegen mangelnder fachlicher Ausbildung dieser Fotografen wurde massenweise fotografisches Material vergeudet, sodass der Chef der Propagandaabteilung Folgendes berichtete: 'Man kann sagen, dass der Schaden fast größer ist als der Nutzen. Die Aufnahmen sind mehrheitlich unscharf und nicht künstlerisch, das heißt ohne jegliches Geschick eines Reporters gefertigt. In dieser Zeit wurden 154 unterschiedliche Aufnahmen gemacht, von denen 139 ziemlich schlecht und 15 überhaupt nicht gelungen sind. Außerdem ist auf den Filmen vieles unentwickelt 
geblieben, weil der Reporter offensichtlich immer noch nicht mit den Grundbegriffen der Fotografie vertraut ist. Wir haben keinen besseren Reporter in der Brigade, weshalb wir uns vorübergehend auch mit ihm zufriedengeben und seine Arbeit natürlich streng kontrollieren müssen. « ${ }^{44}$

Die Brigade schaffte es dennoch, sieben Ausstellungen zu organisieren, bei denen 18 Fotografien die Stellungen der Brigade, 16 die Sitzungen der Sanitätstruppe, 23 die Feier anlässlich des Jahrestags der Gründung der Roten Armee und 16 die Manöver der Brigade zeigten. Genauso wie in anderen Brigaden fehlten hier Fotografien von der vordersten Front und der unmittelbaren Kämpfe gegen den Feind. Vereinzelt wurden Fotografen wegen Feigheit vor dem Feind oder wegen Verrats bestraft, doch das häufigste Problem war ihre Unachtsamkeit. ${ }^{45}$ In der Fotosektion der 21. Serbischen Stoßbrigade kam es auch zu persönlichen Problemen mit den Fotografen:

"Sie machten sich mit ihren Fotoapparaten wichtig und hielten sich zumeist in der Nähe der Stäbe auf, um die Offiziere zu fotografieren. Dem Politkommissar Mirko Jovanović missfiel ihre ständige Präsenz in der Nähe der Stabsoffiziere und er wünschte sich sehnlichst, sie an vorderster Front zu sehen, wie sie die Feuerstellungen der Partisanen sowie ihre Angriffe und ihre Abwehr feindlicher Attacken fotografieren.«46

Statt ihnen einen strengen Befehl zu erteilen, gelang es dem Kommissar jedoch, sie für seine Idee zu begeistern und sie zu motivieren, an die vorderste Front zu gehen. Binnen zehn Tagen organisierten sie bereits eine Ausstellung, die großen Erfolg hatte.

»Die Anwesenheit der Fotoreporter an den vordersten Frontlinien, in den Schützengräben und Unterständen löste bei den Soldaten und Offizieren ein reges Interesse und große Neugierde aus. Mancherorts gab es jedoch Spott und Häme. Die Fotoreporter hatten keine Zeit, darauf zu reagieren, da sie unaufhörlich fotografierten. Manche von ihnen waren dann an den direkten Kampfhandlungen beteiligt, erlebten ihre Feuertaufe und machten dabei Aufnahmen, die historischen Wert besitzen.«47

Dass sich die materiell-technischen Bedingungen auf die Organisation der Propagandatätigkeit auswirkten, zeigt das Schreiben der Propagandaabteilung des Oberkommandos an den Stab des Fünften Korps vom 1. Dezember 1944, demzufolge alle Fotoapparate vom Typ Leica, »die sich bei einzelnen Partisanen befinden und ihrem persönlichen Vergnügen dienen «, eingeschickt werden mussten. ${ }^{48}$ Des Weiteren ist dem Dokument zu entnehmen, dass die Fotosektion des Oberkommandos keinen einzigen qualitativ hochwertigen Fotoapparat besaß, weshalb den Stäben der Korps die Übersendung der Fotoausrüstung auferlegt wurde. ${ }^{49}$

\footnotetext{
44 Izveštaj Propagandnog odsjeka 5. brigade od 15. ožujka 1945. godine o radu kulturno-prosvjetne sekcije od 15. veljače do 15 . ožujka 1945. godine. In: Jovanović, Stanimir und Mirčetić, Dragoljub. Peta srpska NOU brigada. Belgrad: Vojnoizdavački i novinski centar 1989, S. 289

45 Belgrad, Militärarchiv, NOVJ [Volksbefreiungsarmee Jugoslawiens], K60B F5 22.

46 Gončin, Milorad. U rovovima Srema. Belgrad: NIRO Eksport-pres 1981, S. 210.

47 Ebd.

48 Belgrad, Militärarchiv, NOVJ [Volksbefreiungsarmee Jugoslawiens], K460C F29 8.

49 Ebd.
} 
Zu Beginn des Jahres 1944 war in den Propagandasektionen des Hauptstabs für Slowenien und des Slowenischen Volksbefreiungsrates der militärische vom zivilen Fotodienst getrennt. Die als Soldaten dienenden Fotografen, die in den militärischen Einheiten aktiv waren, hatten die Aufgabe, vor allem Kriegsoperationen zu dokumentieren. Sie waren ständig in Bewegung und in unmittelbare Kämpfe gegen den Feind verwickelt. Ein zweiter Teil der Fotografen sollte wiederum Aufnahmen auf dem befreiten Territorium machen und die Folgen der feindlichen Verwüstungen sowie die Zerstörung von zivilen und wirtschaftlichen Objekten festhalten. Damit der Fotodienst funktionieren und ein zentrales Fotoar-

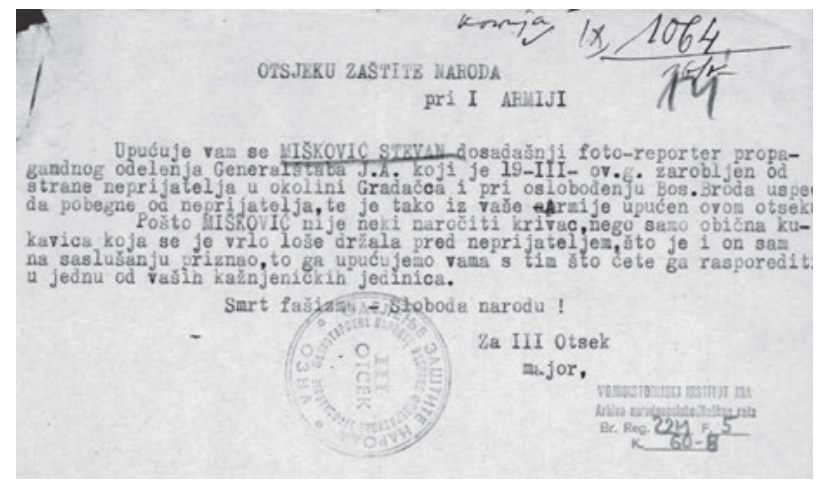

Überstellung eines befreiten Fotografen an den jugoslawischen Geheimdienst mit der Bitte, diesen wegen schlechter Haltung vor dem Feind in ein Strafbataillon zu überführen. Belgrad, Militärarchiv | NOVJ K60B F5 22.

Military Mission of tho Nationa! L iberation Commicee of Jugoslavia in Great Britzin - Ollice ... . iro.

$$
\begin{array}{ll}
\text { Ret. Ne } & \pi / H / 2 Y Y \\
28 \text { Febr. } & 1945
\end{array}
$$

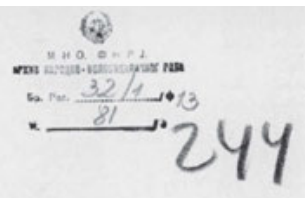

Mol1 sl1ke. BAZI NARODNO OSLOBODIIACKE VOJSKE JUGOSLAVI JS

$$
\text { B A R I }
$$

Za propegandne svrhe ovdje eu nam hitno 1 neophodno potrebne dobre slike 1 to: $1 \mathrm{z}$ borbe ( narodito $21 \mathrm{mi}$ ), - bolnicama, ranjenicima 1ta, al1 1 sve druge dobre slike naroǒito novijeg datuma korleno be se upotrebit1.

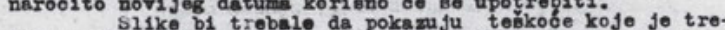
balo prebrodit1 a postignuce o1lja (enijeg,blato, nedostatak maters

Takodjer b1 b1le potrebne sike (evel) 1z knj1ge "5 ofanziva" koju b1 polubsil ovdje da tikkamo na ongl ",s ov. I franouskom Jeriku. Ako imate zapise pojedinaca koj1 ou ucestrovali u petof ofanzivi molim da in takodjer dostavite.

kolimo da ore sl1ke ǩto prije poěaljete ev. preod njega stvar1 najbrže st1ju.

8mrt fă̌1 zma - Sloboda narodul

Za g̀efa ureds, kapetan

Der in Bari, Italien, stationierte Stab der Volksbefreiungsarmee Jugoslawiens fordert Fotomaterial zu Propagandazwecken an, vor allem Bilder, die Kampfszenen im Winter, Krankenhäuser, Verwundete etc. zeigen. Ziel ist es, die Schwere des Kampfes darzustellen. Belgrad, Militärarchiv | NOVJ K113B F2 8. 
chiv angelegt werden konnte, waren alle Fotografen verpflichtet, ihre Negative direkt an den Hauptstab zu schicken. ${ }^{50}$ Unterschiedlichen Schätzungen zufolge arbeiteten in der slowenischen Partisanenbewegung annähernd 150 Fotografen.

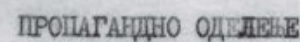
BPXOBHOГ ШTABA

Beorpen 1 XII $1944 \mathrm{r}$.

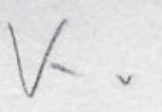

IIATBY $\bar{V}$ Kopriyea
3. 3690 - Th:

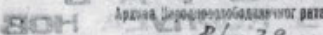
Bp. Rar. $8 / 2-2910$ K $4 \sigma_{0} \mathrm{Cl}$

Iіропатяино оделење

Савесио прикупите и што хитиије удутите овоме оделеву:

1) По једку хопију од свих фотографија са којима располаве Вама фоото секција и секције евих подручиих Вем јадиница. - У обвир полазе првенствено фоотограф̆ије које илуструју напу борбу и вверска пела окупатора. На потеђини сваке фотографије написати шта она преставља.

2) Фотографије свих истаккутих војних и политичикх руховодилаца, хероја, и уопште одликованих хуок бораца. Уу волико не располаве са поменутим снимцияа, иввршити одмах фортограф̆исање хивих другова и предувети све потребне мере да се пронаһу и фоотограс̆ије погинулих другова.

3) По један примерак реяних листова, прогласа, пјесмарица, брошура и сличиих "штампаних" иядања наших јединица - оп 1941 до данас, наравко од оних које су сачуване.- Предузети потребне хере да се код појединаца сачуваии материјал пронађе и прикупи.

Све ово потребно је ва Архив Врховног штеба, као материјал за историју наше борбе.

4) Све форто апарате типа "Јаика", Формат $24 \times 36$ ма који се налазе код поједонаца и слузе ва вихвво лично вяловољетве.

Фото секција Вреховног штаба не располеже ии са једник добрим апаратом, вато ово питање схватите као врло важно и хитно.

Поред тога, неопходно је потребно, да водите евиденцију о свия ратним трофејика, веваних за повнатијвх борбе, које су наше јехимице водиле са непријатеьем. Попис трофеја и легенца ув исте треба иввршити што пре, Друговима који поседују неке оп трофеја ( револвер и сл) треба објасиити да им се трофеји неһе одувимати, нето да hе једиво, по потреби, бити увети на послугу ва време трајава ивлокби, хоје ияамо мемкеру да приредимо,

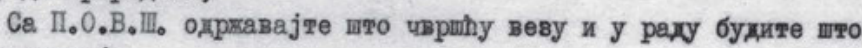
өкспедитивни ји.

$$
\text { C мрт фашиягу - слобода народу } 1 .
$$
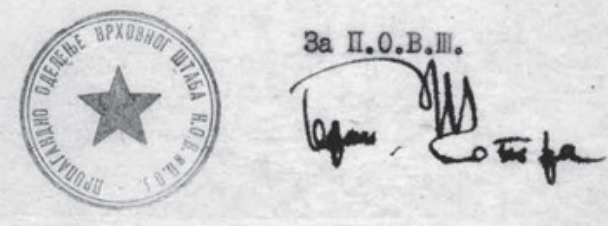

Anweisung der Propagandaabteilung des Generalstabs, wichtiges Fotomaterial und Fotoapparate der Marke Leica zu senden. Belgrad, Militärarchiv | NOVJ K113B F2 8.

50 Fabec, Franc. Photography during the Slovene National Liberation Struggle. In: Pirjevec, Jože und Repe, Bože (Hrsg.). Resistance, Suffering, Hope: The Slovene Partisan Movement 1941-1945. Ljubljana: National Committee of Union of Societes of Combatants of the Slovene National Liberation Struggle Ljubljana, Trieste: Založništvo tržaškega tiska Trieste in cooperation with Slovenska kulturno gospodarska zveza 2008, S. 97-99. 
Laut Bericht der Propagandaabteilung des Hauptstabs der Volksbefreiungsarmee für Slowenien vom 1. Januar 1945, der an die Propagandaabteilung des Oberkommandos der Armee gerichtet war, wurden insgesamt 15 Exemplare der Ausstellung Sahrana generallajtanta Franca Rožmana-Staneta (Begräbnis des Generalleutnants Franc Rožman-Stane) an die Truppen geschickt, bei denen die Fotografien zusammen mit einem entsprechenden Text auf Leinwänden montiert waren. ${ }^{51}$ In den gleichen Zeitraum fielen die Vorbereitungen für die Ausstellung Rušimo komunikacije (Sprengung der Kommunikationen), die den erfolgreichen Aktionen der Diversanten gewidmet war, sowie für die Ausstellung über die italienische Division Fontanot und den Kriegszug der 24. Division mit Fotografien von Jože Petek. Angeführt wurde, dass es für diese Ausstellungen an Material, am meisten an Fotopapier für die Vergrößerung der Fotografien, fehle. ${ }^{52}$ Der Mangel an Fotomaterial setzte sich weiterhin fort, wie im Bericht derselben Propagandaabteilung vom 1. Februar 1945 zu lesen ist. Die Arbeit in der Fotosektion sei aber überaus rege, sodass in der Zeit vom 14. bis 24. Januar 1945 in Črnomelj eine Ausstellung der 24. Division stattfinden konnte. Für den Hauptstab der Volksbefreiungsarmee und der Widerstandsbewegung Sloweniens erstellte man ein Fotoalbum mit allen zusammengetragenen Fotografien, das in der Folgezeit auch das Oberkommando der Armee erreichte. ${ }^{53}$ Im Bericht vom darauffolgenden Monat wurde die Krise nunmehr für überwunden erklärt. Die Fotowerkstatt hätte 4.023 Fotografien unterschiedlichen Formats angefertigt, auf denen auch Szenen der Kampfhandlungen, der Arbeit und des alltäglichen Lebens zu sehen seien. ${ }^{54}$ Die 26. Stoßdivision organisierte in Tržič Ausstellungen, deren Begleittexte ins Italienische und Englische übersetzt wurden und die eine mobile Bibliothek flankierte. 200 Fotografien im Format $16 \times 24,18 \times 24,26 \times 38$ und $13 \times 18 \mathrm{~cm}$ wurden auf 15 Papptafeln geklebt.

Dass angelernte Amateurfotografen bis zum Kriegsende an der Arbeit der Fotodienste beteiligt waren, besagt auch der Bericht des Operativen Stabes für Istrien vom 23. April 1944. Über die Zustände vor Ort wird unter anderem mitgeteilt:

\begin{abstract}
"Die Kultur- und Bildungsarbeit erfolgt nicht nach einem vorher erstellten Plan und sie ist unorganisiert. [...] Wir beabsichtigen, eine Fotosektion zu organisieren. Eine Werkstatt für die Vervielfältigung und Entwicklung haben wir schon. Wir suchen einen guten Fotografen für unseren Stab. $\aleph^{55}$
\end{abstract}

Die fundierte Analyse der heute bestehenden Archive und die Sichtung zahlreicher Untersuchungen, die sich in den letzten Jahren mit dem Thema der Partisanenkunst von 1941 bis 1945 beschäftigt haben, lassen den Schluss zu, dass die Partisanenkunst nur schwer als eine Kulturproduktion nach heutiger Definition angesehen werden kann. Indes handelt es sich bei der Partisanenkunst um eine besondere Form der Politik, die trotz der Zentralisie-

\footnotetext{
51 Zbornik dokumenata i podataka o narodno-oslobodilačkom ratu jugoslovenskih naroda. Bd. IX/3: Partijsko-politička dokumenta 1943. godine. Belgrad 1967.

52 Ebd.

53 Ebd.

54 Ebd.

55 Zbornik dokumenata i podataka o narodno-oslobodilačkom ratu jugoslovenskih naroda. Bd. V/26: Borbe u Hrvatskoj 1944.

godine. Belgrad 1961.
} 


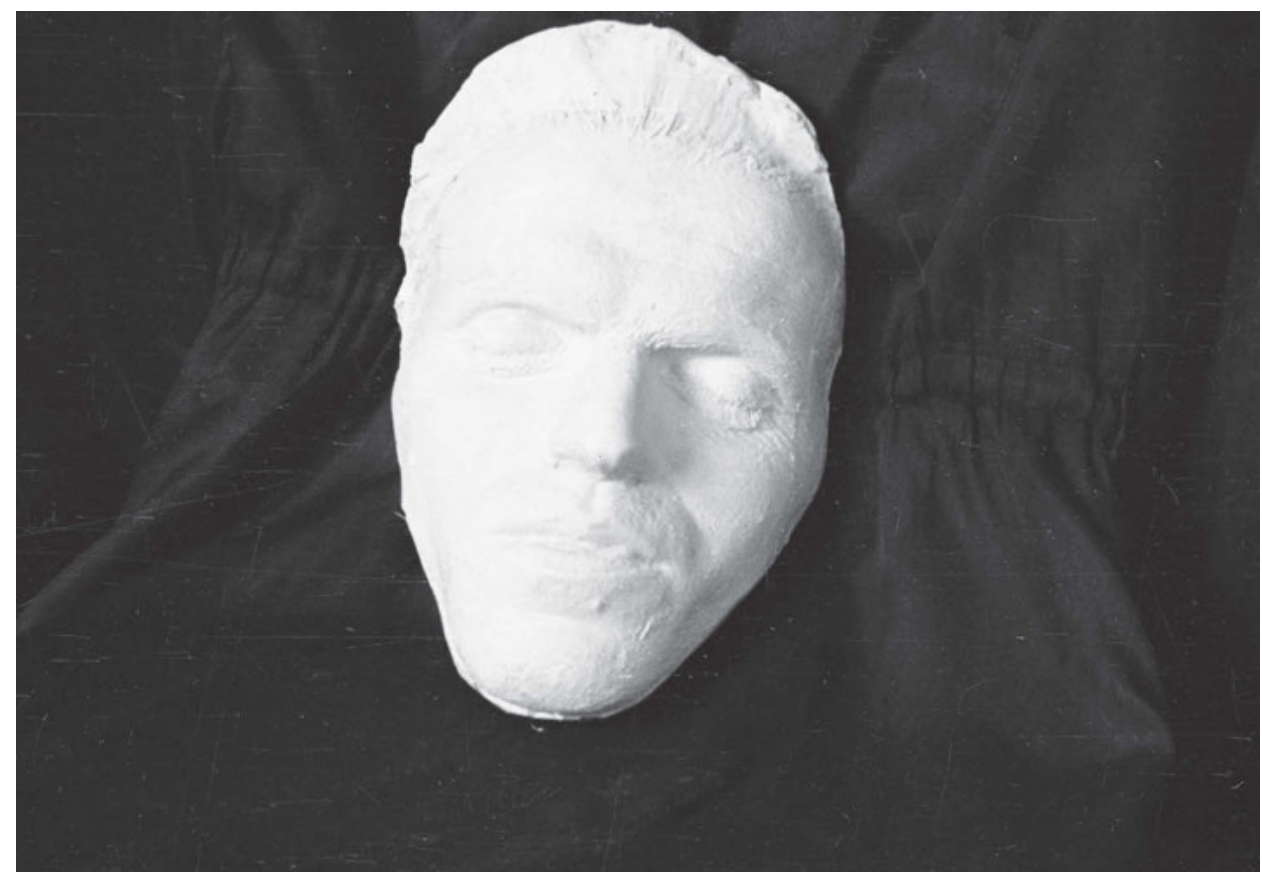

Totenmaske von Franz Rozman-Stane, Črnomelj, 8. November 1944. Foto: Peter Jelič. Ljubljana, Museum für Neuere Geschichte Sloweniens | TN440/16.

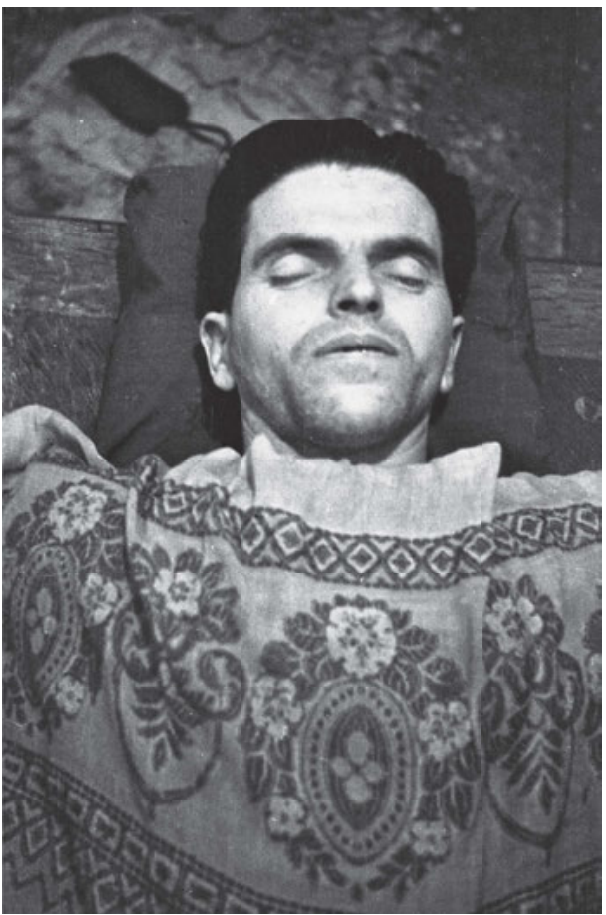

Der verstorbene Franz Rozman-Stane auf dem Sterbebett, Črnomelj, 8. November 1944.

Foto: Peter Jelič. Ljubljana, Museum für Neuere Geschichte Sloweniens | TN440/16.

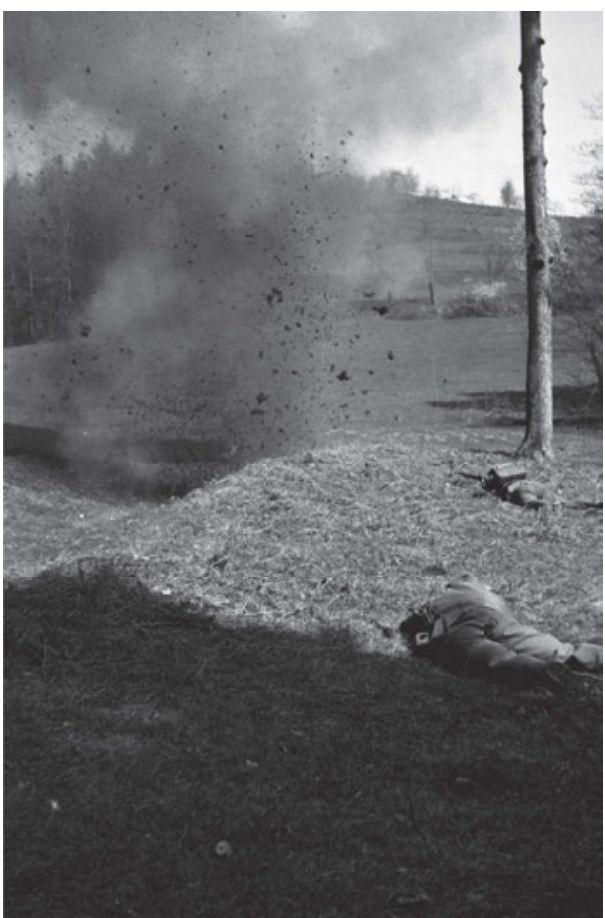

Explosion einer Granate, August 1943. Fotograf unbekannt. Ljubljana, Museum für Neuere Geschichte Sloweniens | TN27/40. 


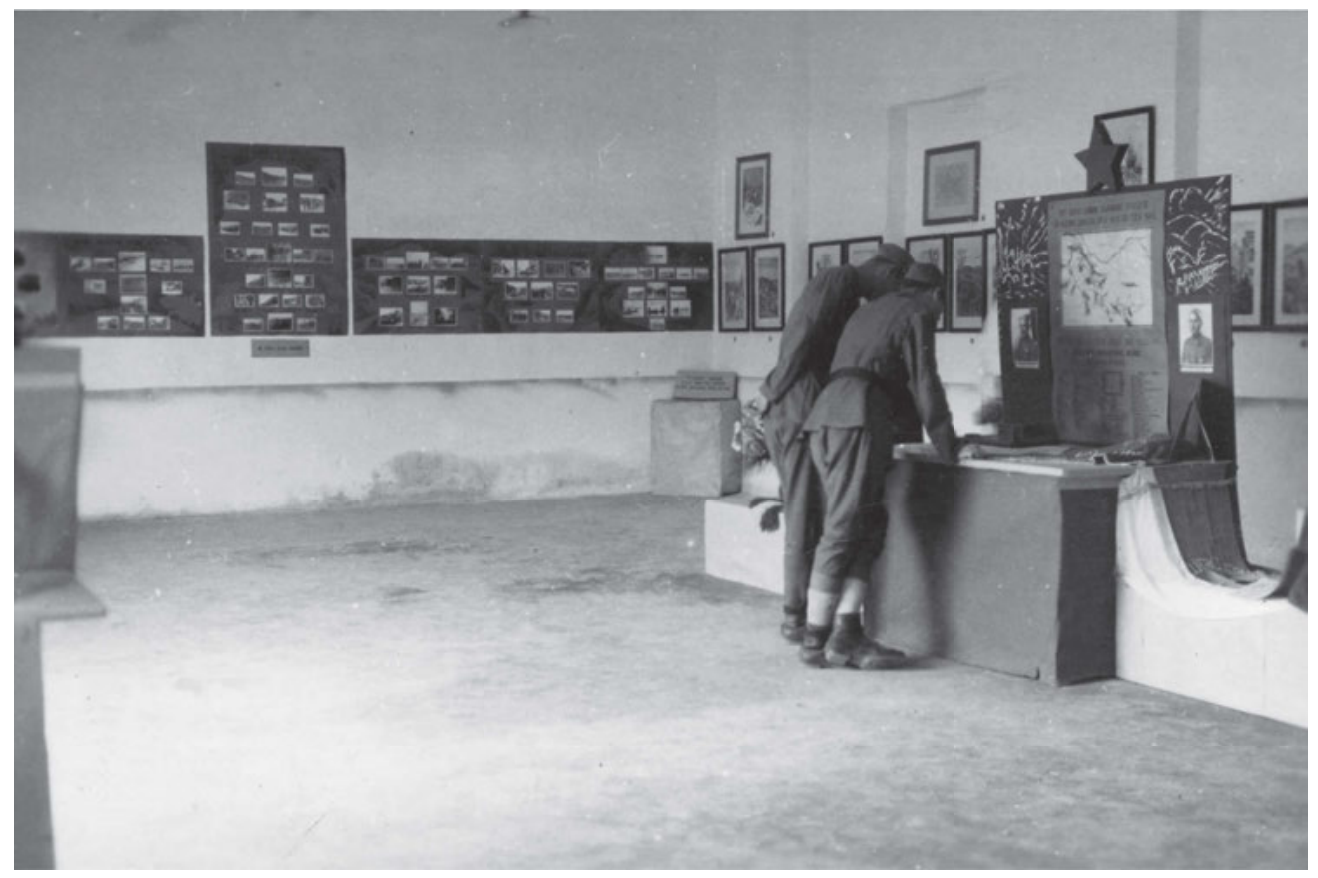

Ausstellung in Samobor, Kroatien, am 6. Juni 1945. Fotograf: Vlado Potočnjak. Zagreb, Kroatisches Historisches Museum | HPM/MRNH-F-9155.

rung des Befreiungskampfes ein bestimmtes Maß an Autonomie erreichen konnte. ${ }^{56}$ Hierin liegt auch die Bedeutung der Partisanenfotografie, da gerade die politische Sprache und die Mechanismen, die sie während des Volksbefreiungskampfes anwendete, ihr aktivistisches Potenzial betonen.

Die Partisanenfotografie kann daher nicht ausschließlich auf Propagandafotografie reduziert und nicht nur als Teil des Propagandaapparats betrachtet werden. Obwohl die Idee der Zentralisierung der Organisation, in deren Rahmen auch die Fotosektionen wirkten, von Anfang an präsent war, geht aus dem vorliegenden Material hervor, dass die Partisanenfotografie in der Zeit zwischen 1941 und 1943 vor allem dank des persönlichen Mutes und Enthusiasmus einzelner Partisaninnen und Partisanen existierte. In den Jahren 1944 und 1945 folgte eine ganze Reihe von Verordnungen, die die Rolle der Fotosektionen innerhalb des Propagandaapparates zu bestimmen suchten, was jedoch erst nach Ende des Krieges im Jahr 1945 gänzlich erreicht wurde. Die Zentralisierung des gesamten Apparats war in erster Linie durch die Konsolidierung der Macht des neuen Staates und die von außen herangetragenen Sicherheitseinschätzungen bezüglich einer potenziellen sowjetischen Okkupation des Landes bedingt. Erst nach der Resolution des Informationsbüros und dem Zerwürfnis mit der UdSSR 1948 wurden die »dogmatischen Anschauungen im Bereich der Bildung und Kultur verworfen, die den sowjetischen Erfahrungen entnommen wurden «. ${ }^{57}$

56 Kirn, Gal. On the Specific (In)existence of the Partisan Film in Yugoslavia's People's Liberation Struggle. In: Jakiša, Miranda und Gilić, Nikica (Hrsg.). Partisans In Yugoslavia: Literature, Film and Visual Culture. Bielefeld: transcript Verlag 2015, S. 207.

57 Petranović, Branko. Istorija Jugoslavije 1918-1988. Bd. 3: Socijalistička Jugoslavija 1945.-1988. Belgrad: Nolit 1988, S. 319. 
